\title{
Lisanslı Fotovoltaik Güneş Enerji Santrali Yatırımının Finansal Analizi: Van İli Örneği
}

\author{
Mehmet YALILI* \\ Gazi Üniversitesi, Teknoloji Fakültesi, Enerji Sistemleri Mühendisliği Bölümü, Ankara \\ (ORCID: 0000-0002-6636-833X)
}

\begin{abstract}
Öz
Bu çalışmada, lisanslı ve şebekeye bağlı $1 \mathrm{MW}$ gücündeki fotovoltaik GES yatırımının günümüz ekonomik koşullarına göre finansal analizi yapılarak yatırımın kârlı olup olmadığı incelenmiştir. Bu kapsamda öncelikle ülkemiz güneş enerjisi potansiyel atlasından faydalanılarak Van ili Edremit ilçesinin GES kurulumu için uygunluğu değerlendirilmiş ve arazi seçimi yapılmıştır. Enerji hesaplamalarının yapılmasında PVGIS çevrim içi veri tabanından yararlanılmış ve seçilen arazi için yıllık elektrik üretim miktarı hesaplanmıştır. Yatırımın ekonomik ömrü olan 25 yıl boyunca panel veriminde yıllık \%0.7 oranında lineer düşüş olacağı varsayılmıştır. Yatırımın fayda ve masraf unsurları, her birine karşılık gelen güncel yatırım maliyetleri belirtilerek detaylı şekilde açıklanmıştır. Yatırımın tamamen öz sermaye veya on yıl geri ödemeli TurSEFF yenilenebilir enerji kredisi ile yapılması durumları için geri ödeme süresi (GÖS), net bugünkü değer (NBD), iç kârlılık oranı (IKO) ve fayda/masraf oranı (FMO) yöntemleri kullanılarak finansal analiz gerçekleştirilmiştir. Mevcut alım garantisi fiyatları ile serbest piyasada gerçekleşen elektrik satış fiyatları (piyasa takas fiyatı) esas alınarak yapılan değerlendirmeye göre, \%10 kâr payı beklentisi altında yatırımın öz sermaye ile yapılması halinde NBD pozitif, FMO 1'den büyük ve İKO \%22.35 olarak hesaplanmış, bu durumda yatırımın geri ödeme süresi 4 yıl olarak bulunmuştur. Yatırım maliyetlerinin kredi ile karşılanması halinde ise NBD negatif olarak hesaplanmış, ayrıca FMO 0.928 , IKKO \%6.76 ve geri ödeme süresi 9 yıl olarak bulunmuştur. Finansal analize örnek olarak seçilen Van ilinde gerçekleştirilen 1 MW GES yatırımının öz sermaye ile yapılması halinde kabul edilebileceği, ilk yatırım maliyetlerinin tamamen kredi ile karşılanması halinde ise yatırımın yapılabilir olmadığı sonuçlarına ulaşılmıştır.
\end{abstract}

Anahtar kelimeler: Güneş enerjisi, finansal analiz, PVGIS, fizibilite çalışması, lisanslı üretim.

\section{Financial Analysis of Licensed Solar PV Investment: A Case Study of Van Province}

\begin{abstract}
In this study, financial analysis of the licensed and grid-connected $1 \mathrm{MW}$ photovoltaic solar power plant investment according to today's economic conditions was made and it was examined whether the investment is profitable or not. First of all, the suitability of the Edremit district of Van province for the solar PV installation was evaluated by using our country's solar energy potential map, and land selection was made accordingly. PVGIS online database was used for energy calculations, and the annual electricity generation for the selected land was calculated. It is assumed that the efficiency of solar PV panels will decrease linearly by 0.7 percent per year over the course of the investment's economic life of 25 years. The investment's benefit and cost elements were thoroughly outlined, including current investment costs corresponding to each item. For cases where the investment is made entirely with equity capital or a TurSEFF renewable energy loan with a ten-year repayment term, financial analysis was performed using methods of payback period (PBP), net present value (NPV), internal rate of return (IRR), and benefit cost ratio (BCR). According to the analysis based on current purchase guarantee and market clearing prices, if the investment is made with equity and a $10 \%$ profit margin is anticipated, the NPV is positive, the BCR is greater than 1 and the IRR is 22.35 percent. The investment's payback period was found to be 4 years in this case. However, if the loan covers the investment costs, the NPV is negative, the BCR is 0.928 , the IRR is 6.76 percent, and the payback period is 9 years. The evaluation of the $1 \mathrm{MW}$ SPP investment conducted in Van province, which was chosen as a case study for financial analysis, concluded that an affirmative investment decision could be made if the investment was made with equity capital, and that if the investment was entirely funded by loan, the investment could not be deemed feasible.
\end{abstract}

Keywords: Solar energy, financial analysis, PVGIS, feasibility study, licensed electricity generation.

"Sorumlu yazar: mehmetyalili@hotmail.com

Gelis Tarihi: 22.03.2021, Kabul Tarihi: 13.07.2021 


\section{Giriş}

Güneş enerjisi kaynağını güneşten alan ve güneşin çekirdeğinde gerçekleşen füzyon reaksiyonu sonucu açığa çıkan radyasyon (1şınım) enerjisidir. Atmosfer dolayısıyla bu enerjinin yeryüzüne ulaşan miktarı $0-1100 \mathrm{~W} / \mathrm{m}^{2}$ arasında değişmektedir. Dünyada güneş enerjisinden elektrik üretiminde faydalanılması konusunda özellikle 1970'lerden itibaren çalışmalar hız kazanmıştır. Ayrıca, yaşanan teknolojik gelişmeler ve maliyetlerdeki düşüşler ile küresel ısınma ve iklim değişikliği gibi sebepler doğrultusunda yenilenebilir enerji kaynakları arasında yer alan ve temiz enerji olarak nitelenen güneș enerjisinin önemi gün geçtikçe artmıştır. Güneş enerji santrallerinin (GES) kurulumu hidroelektrik, rüzgâr ve jeotermal enerji santrallerine kıyasla daha kısa sürede tamamlanabilmekte ve bu santraller kurulumundan sonra daha düşük maliyetle işletilebilmektedir [1].

Türkiye $36^{\circ}-42^{\circ}$ kuzey paralelleri arasında orta kuşakta yer almakta olup güneş enerjisi potansiyeli yüksek olan ülkeler arasındadır. Meteoroloji Genel Müdürlüğü (MGM) tarafından hazırlanan Türkiye'de 1988-2017 yılları arasında gerçekleşen ortalama günlük güneşlenme sürelerinin dağılımı Şekil 1'de gösterilmiştir. Türkiye'de ortalama en yüksek günlük güneşlenme süresi Temmuz ayında yaklaşık 11.3 saat/gün iken en düşük güneşlenme süresi ise Aralık ayında 3.5 saat/gün şeklinde gerçekleşmiştir [2]. Şekil 1 incelendiğinde, Güneydoğu Anadolu, Ege ve Akdeniz kıyıları ile Doğu Anadolu Bölgesinde yer alan illerin, diğer coğrafi bölgelerde yer alan illere kıyasla daha yüksek ortalama günlük güneşlenme sürelerine sahip olduğu görülmektedir.

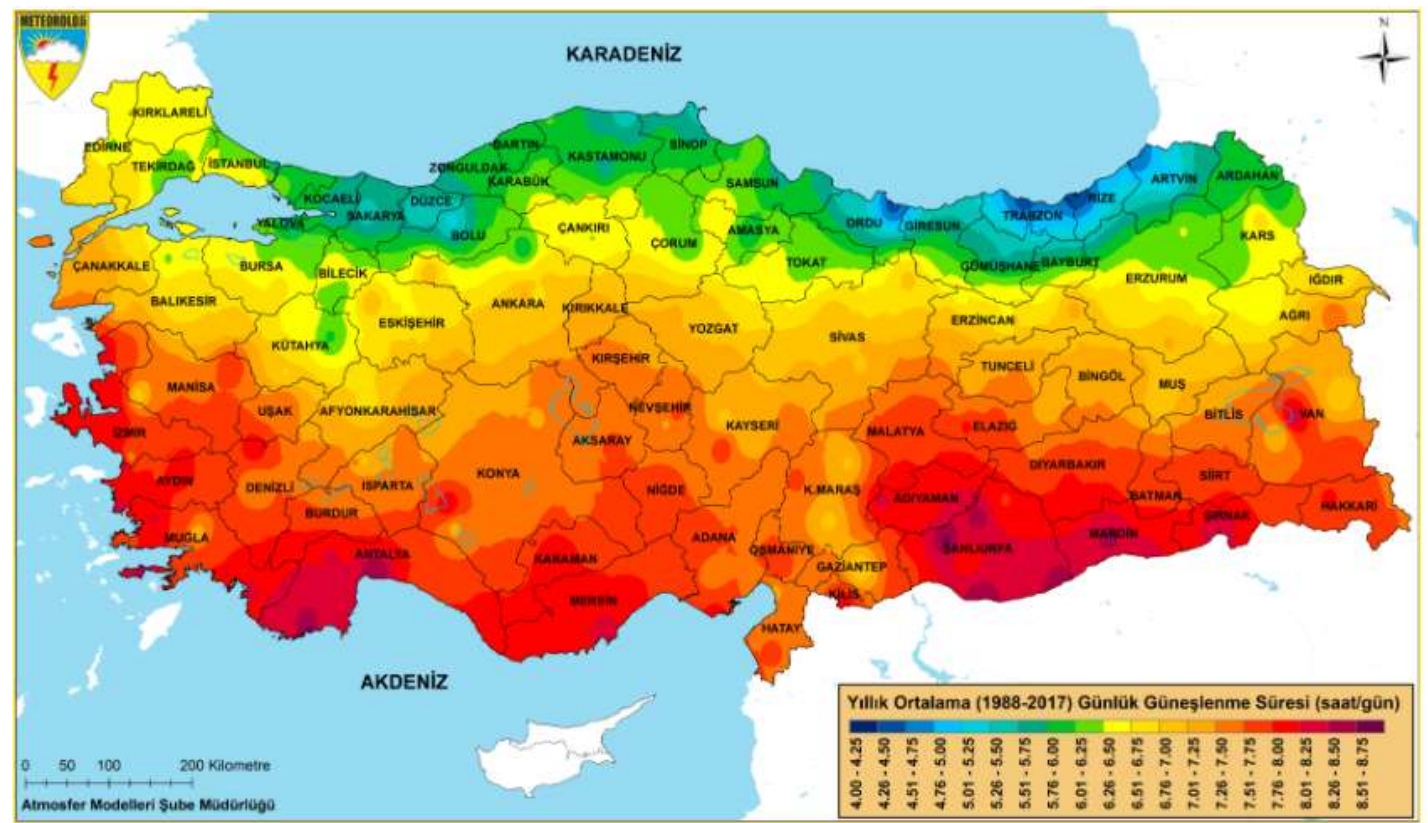

Şekil 1. Türkiye'nin 1988-2017 yılları arasındaki yıllık ortalama günlük güneşlenme süreleri (saat/gün)

Enerji ve Tabii Kaynaklar Bakanlığı (ETKB) tarafından hazırlanan Türkiye Güneş Enerjisi Potansiyel Atlası (GEPA) verilerine göre; Türkiye'nin ortalama yıllık toplam güneşlenme süresi 2741.07 saat/yıl, ortalama günlük toplam güneşlenme süresi 7.5 saat/gün, ortalama y1llık toplam 1şınım şiddeti $1527.46 \mathrm{kWh} / \mathrm{m}^{2}$-yıl ve ortalama günlük toplam 1 şınım şiddeti $4.18 \mathrm{kWh} / \mathrm{m}^{2}$-gün şeklindedir [3].

Güneş enerjisinden elektrik üretimine olan talep, güneş enerjisinin temiz, yerli ve yenilenebilir kaynak olması, enerjide dışa bağımlılığı azaltıcı ve karbon salımını düşürücü etkileri dolayısıyla tüm dünyada olduğu gibi ülkemizde de hızla artmaktadır. Ocak 2021 sonu itibarıyla Türkiye'nin güneş enerjisine dayalı toplam kurulu gücü $6805.8 \mathrm{MW}$ 'a ve Türkiye'nin toplam kurulu gücü içindeki pay1 \%7.1 seviyesine ulaşmıştır [4]. Türkiye'de güneş enerjisine dayalı elektrik üretim tesisleri lisanslı üretim, lisanssız üretim veya yenilenebilir enerji kaynak alanları (YEKA) modeli kapsamında kurulabilmektedir [5]. Lisanslı üretim ve YEKA modeline göre güneş enerji santrali kurabilmek amacıyla sisteme bağlantı kapasitesi elde edenleri belirlemek amacıyla sırasıyla Türkiye Elektrik İletim A.Ş. tarafından kapasite tahsis yarışmaları ve ETKB tarafindan YEKA ihaleleri uygulanmakta olup bu yarışmaları kazanan tüzel kişilere üretim tesislerini kurabilmek amacıyla Enerji Piyasası Düzenleme 
Kurumu (EPDK) tarafindan Elektrik Piyasası Lisans Yönetmeliği kapsamında önlisans ve akabinde üretim lisansı verilmektedir. Lisanssız üretim içinse herhangi bir yarışma sistemi bulunmamakta, ilgili başvurular Elektrik Piyasasında Lisanssız Elektrik Üretim Yönetmeliği uyarınca sonuçlandırılmaktadır.

Ülkemizde mevcut durumda kurulu ve işletmede olan GES'lerin \%93.4'ünü lisanssız üretim kapsamındaki santraller oluşturmakta olup lisanslı üretim faaliyeti gösteren GES'ler, YEKA modeli kapsamındaki Karapınar YEKA-1 GES projesi de dâhil olmak üzere 38 adet ve 445.9 MW kurulu gücündedir [6]. Lisanslı üretim tesislerinin kurulumu, lisanssız üretim modeline kıyasla idari süreçlerin daha fazla olması ve mevzuat kaynaklı yükümlülüklerin yerine getirilmesi zorunluluğu nedeniyle daha uzun sürebilmektedir. Dolayısıyla öncelikle öz tüketimin karşılanarak ihtiyaç fazlası elektriğin sisteme verilmesi amacıyla kurulacak GES'lerin lisanssız üretim modeli kapsamında; şebekeye bağlı olarak çalışacak orta ve büyük ölçekli GES'lerin ise lisanslı üretim modeli kapsamında gerçekleştirilmesinin uygun olacağı değerlendirilmektedir.

Güneş enerjisi kaynak potansiyelinin belirlenmesi, değerlendirilmesi ve santral kurulumlarına ilişkin çeşitli akademik çalışmalar yürütülmüştür. Bu kapsamda yapılan bir çalışmada [7], Sivas Cumhuriyet Üniversitesi yerleşkesinde $1 \mathrm{MW}$ gücündeki GES yatırımının ekonomik analizi PVsyst programı yardımıyla yapılmış, polikristal ve monokristal panellerin kullanılması durumları karşılaştırılarak monokristal panellerle kurulan santralin 30 yıllık ekonomik ömrü boyunca polikristal panellere göre daha yüksek kazanç sağlayacağı ancak kurulum maliyetinin daha fazla olacağ görülmüştür. Yapılan diğer bir çalışmada [8], Van ilinin güneş enerjisi potansiyeli incelenerek mevcut durum hakkında detaylı bilgilere yer verilmiş ve çeşitli uygulama örnekleri gösterilerek güneş enerjisinden yararlanma oranının artırılması için çeşitli değerlendirme ve öngörülerde bulunulmuştur. Başka bir çalışmada [9], Sivas ilinin beş farklı ilçesinde $10 \mathrm{MW}$ kurulu gücünde GES kurulumu monokristal ve polikristal paneller kullanılarak PVsyst programı yardımıyla gerçekleştirilmiş, yatırımın banka kredisi kullanılarak ve kullanılmadan yapılması durumları ekonomik açıdan değerlendirilmiştir. Diğer bir çalışmada [10], Aydın ili Çine ilçesinde 1 MW gücünde bir güneş enerji santrali kurulumunun ekonomik analizi, enerji hesaplamaları PVSOL programı kullanılarak gerçekleştirilmiş, yatırımın geri ödeme süresi ve iç karlılık oranı hesaplanmıştır. Başka bir çalışmada [11], şebekeye bağlı $1220 \mathrm{MW}$ gücündeki bir güneş enerji santralinin Burdur gölü civarında uygulanabilirliği değerlendirilmiş, bu kurulumun ülke ekonomisine ve yenilenebilir enerjiye dayalı kurulu güce büyük oranda katk1 sağlayacağı sonucuna varılmıştır. Bir diğer çalışmada [12], mevcut durumda işletmede olan ve elektrik üretimi gerçekleştirilen $200 \mathrm{kWp}$ gücündeki bir güneş enerji santralinin PVsyst programı ile simülasyonu gerçekleştirilerek gerçek elektrik üretim verileri ile karşılaştırma yapılmıştır. Yapılan analiz sonucunda, gerçek üretim değerleri ile PVsyst simülasyonuyla elde edilen sonuçlar arasında $\% 0.56$ oranında oldukça az bir fark olduğu görülmüştür. Yapılan başka bir çalışmada [13], Türkiye'nin güneş enerjisi potansiyeli ve güneş enerjisinin elektrik üretiminde kullanılma oranını belirleyici kriterler kapsamlı şekilde incelenmiş, Karabük ilindeki güneş enerji santrali kurulumlarının mevcut durumu açıklanarak gelecekte bu santrallerin yaygınlaşması için çeşitli değerlendirmelerde bulunulmuştur. Bir diğer çalışmada [14], rüzgar ve güneş enerjisine dayalı potansiyelin belirlenmesi, santrallerin elektrik üretimi ve ekonomik analizinin yapılması için web tabanlı bir yazılım geliştirilmiş ve örnek olarak Bartın ili Amasra ilçesinde $600 \mathrm{~kW}$ gücünde bir rüzgar türbini kurulumu ile $100 \mathrm{kWp}$ gücünde panel kurulumu halinde üretilecek elektrik miktarı, yatırımın geri ödeme süresi ile kâr miktarları hesaplanarak karşılaştırma yapılmıştır. Diğer bir araştırmada [15], Sinop ilinin güneş enerjisi potansiyeli ile Almanya'nın güneş enerjisi potansiyeli ve uygulamaları çeşitli ulusal ve uluslararası veriler yardımıyla kıyaslanarak sonuçlar üzerine değerlendirmelerde bulunulmuştur. Bir diğer çalışmada [16], fotovoltaik çatı GES uygulamasında üretilen elektrik enerjisi miktarı belirlenip yatırımın finansal analizi gerçekleştirilirken başka bir çalışmada [17] ise Uşak ilinde güneş enerji santrali kurulumu için yasal süreçler, kurulum aşamaları ve finansman modelleri detaylı şekilde incelenerek yapılan SWOT analizi ile GES kurulumu için en uygun arazi seçimi gerçekleştirilmiştir.

Bu çalışmada ise Van ili Edremit ilçesinde seçilen bir arazi üzerinde, lisanslı üretim kapsamında 1 MW kurulu gücündeki bir örnek GES kurulumunun fizibilite analizi yapılarak tüm kurulum süreçleri detaylı şekilde incelenmiş ve yatırımın güncel ekonomik koşullar, güncel mevzuat ve destek mekanizmaları çerçevesinde, santralin ekonomik ömrü boyunca kazançlı olup olmayacağı değerlendirilmiştir. Ayrıca yatırımın öz sermaye veya banka kredisi kullanılarak yapılması durumları için hesaplamalar ayrı ayrı gerçekleştirilerek elde edilen sonuçlar ve yatırımın geri ödeme süreleri karşılaştırılmıştır. Çalışmada PVGIS çevrim içi veri tabanı kullanılarak seçilen arazinin coğrafi 
koordinatlarına göre aylık ve yıllık elektrik üretim miktarları hesaplanmış ve bu kapsamda yatırımın net bugünkü değer, iç kârlılık oranı, fayda/masraf oranı ve geri ödeme süresi yöntemlerine göre finansal analizi gerçekleştirilmiştir. Bu çalışma, lisanslı bir GES yatırımının finansal analizinin elektrik piyasasına ilişkin güncel mevzuat, tarifeler ve alım garantisi mekanizması, elektrik enerjisi spot piyasasında gerçekleşen piyasa takas fiyatları ve güncel ekipman, kurulum, işletme ve bakım maliyetleri esas alınarak gerçekleştirilmesi, Van ili örneğinin incelenmesi, enerji analizinde PVGIS veri tabanının kullanılması ve dört farklı yatırım değerlendirme yönteminin yatırım maliyetinin öz sermaye veya kredi ile karşılanması senaryoları altında eş zamanlı uygulanarak sonuçların karşılaştııılması bakımından alanında özgün bir yapıttır. Bu çalışma sonucunda Van ilinde lisanslı üretim kapsamında yapılacak bir GES yatırımının kurulum ve işletme maliyetine, getiri oranına ve yatırımın geri ödeme süresine ilişkin elde edilen sonuçlar; farklı bölgelerde çeşitli enerji analiz programları, üretim modelleri (lisanssız, şebekeye bağlı veya şebekeden bağımsız) veya farklı finansal analiz yöntemleri kullanılarak yapılacak GES yatırım değerlendirme çalışmalarından elde edilecek sonuçlar ile karşılaştırma yapılmasına olanak sağlayacaktır.

\section{Materyal ve Metot}

Bu bölümde GES yatırımının finansal analizinin gerçekleştirilmesi için sırasıyla, proje için uygun arazi seçimi, aylık ışınım miktarları ile aylık ve yıllık elektrik enerjisi üretim miktarlarının PVGIS yardımıyla hesaplanması, yatırımın fayda ve masraf kalemleri, finansal analizde kullanılan yöntemler ve çalışmada yapılan kabuller kapsamlı şekilde açıklanmıştır.

\subsection{Van ilinin coğrafi özellikleri ve proje için uygun arazi seçimi}

Bir GES yatırımı için en önemli aşama santralin kurulacağı bölgenin ve arazinin seçilmesidir. Bu bağlamda, öncelikle Türkiye'nin güneşlenme sürelerini gösteren Şekil 1'deki haritaya göre seçilen Van ilinin GES kurulumu için uygunluğu incelenmiştir.

Van ili Doğu Anadolu Bölgesi'nde yer alan toplam 21,334 $\mathrm{km}^{2}$ yüzölçümüne ve toplam 1,136,157 nüfusa sahip Türkiye'nin 19 uncu ve bulunduğu bölgenin en kalabalık şehridir. Anadolu'nun en büyük kapalı havzası olan Van Gölü çevresinin toprakları verimli ve akarsular bakımından zengin olup bu bölgede iklim koşulları da oldukça elverişlidir. Van ilinin ortalama rakımı 1730 metredir. Van ilinde en yüksek ortalama sıcaklık Temmuz ayında $22.2^{\circ} \mathrm{C}$ iken en düşük ortalama sıcaklık Ocak ayında -3.5 ${ }^{\circ} \mathrm{C}$ olarak gerçekleşmiştir [18]. Güneş panellerinin birbiriyle verimlilik açısından karşılaştırılmasında standart test değeri olarak $25^{\circ} \mathrm{C}$ panel sıcaklığ $1,1000 \mathrm{~W} / \mathrm{m}^{2}$ güneş radyasyonu ve 1.5 AM hava kütle katsayısı kabul edilir. Sıcaklık artışı modül çıkış geriliminde düşüşe, elektrik enerjisi üretiminde azalmaya ve panel yüzeylerinde bozunmaya yol açar. Dolayısıyla, panel yüzey sıcaklığı arttıkça güneş panellerinin verimi azalmaktadır. Bu nedenle, GES kurulacak bölgenin hava sicaklık ortalaması da oldukça önemli olup panellerin aşırı 1sınmaya maruz kalmaması için doğal hava soğutma ya da cebri hava soğutma sistemi kurulması uygun görülmektedir [19, 34]. Van ilinde y1l boyunca çok yüksek sıcaklıklar görülmediğinden güneş panellerinin daha yüksek verimle çalışması açısından GES kurulumu için uygun bir iklime sahip olduğu söylenebilir. Panel verimini önemli derecede etkileyen bir diğer faktör panel yüzeyinin kirlenmesi veya çevresel faktörler (yağış, ağaç yaprakları, kuş pisliği vb.) nedeniyle kısmen gölgelenmesi ya da tamamen kapanmasıdır. Örneğin kar yağışı halinde panellerin üzerinin kısmen ya da tamamen karla kaplanması durumunda, modülün P-V ve I-V eğrileri önemli ölçüde değiş̧ir, sadece elektrik enerjisinin üretildiği ünitenin verimi düşmekle kalmaz diğer üniteler de bu durumdan etkilenir ve modülün toplam çıkış gücünde düşüş yaşanır. Sonuç olarak güneş panelleri düşük hava sıcaklıklarında, açık havalarda ve yüksek güneş radyasyonuna sahip ortamlarda daha yüksek verimle çalışmakta, kar yağışı veya çevresel faktörlerden kaynaklı kısmi/tam gölgelenme durumlarında panel veriminde ciddi oranda düşüş yaşanmaktadır. Bu nedenle panel yüzeylerinin sıklıkla temizlenmesi panel veriminin artırılması açısından oldukça önemlidir [35]. Van ilinin yıllık ve günlük ortalama radyasyon değerleri Şekil 2 (a) ve Şekil 2 (b)'de gösterilmiştir. 


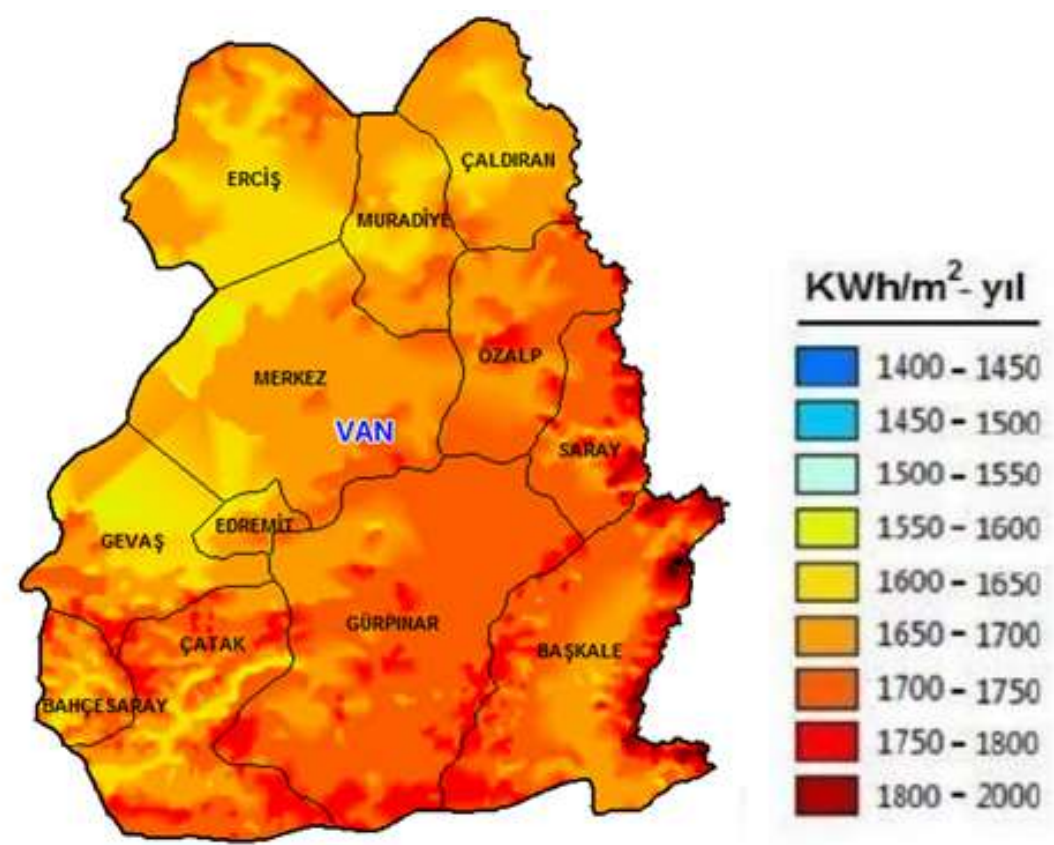

Şekil 2. (a) Van ili yıllık radyasyon değerleri (kWh/m²-y1l) [20]

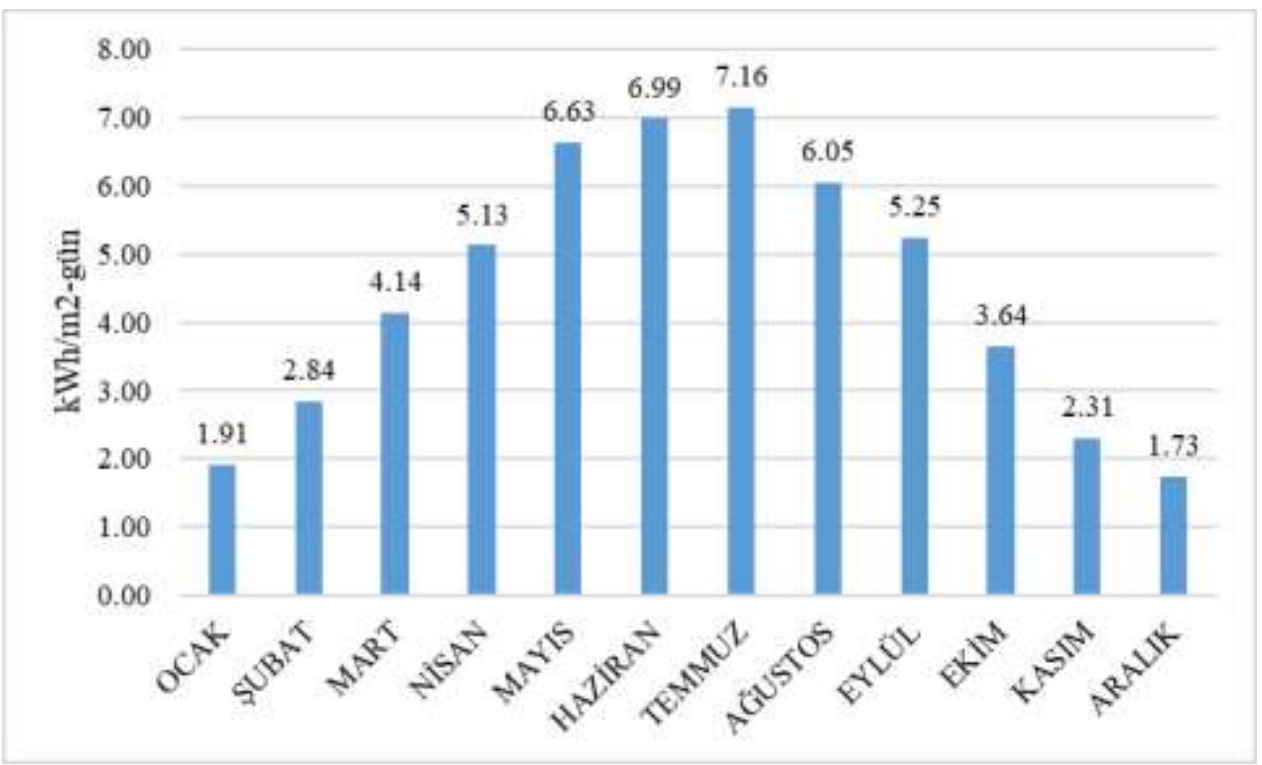

Şekil 2. (b) Van ili günlük ortalama radyasyon değerleri (kWh/m²-gün) [20]

Şekil 2 (a) ve Şekil 2 (b) ile MGM tarafindan sunulan istatistiklere göre, Van ilinin yıllık güneșlenme süresi $3070 \mathrm{saat} / \mathrm{y} 1$; metrekareye düşen y1llık radyasyon miktarı ise $1652 \mathrm{kWh} / \mathrm{m}^{2}$-yıl'dır [21]. Türkiye ortalamalarının sırasıyla 2741.07 saat $/ y 1$ ve $1527.46 \mathrm{kWh} / \mathrm{m}^{2}$-yıl olduğu göz önüne alındığında Van ilinin GES yatırımı için uygun bir il olduğu görülmektedir.

Yatırımın yapılacağı uygun arazi seçimi için değerlendirilmesi gereken başlıca ölçütler şu şekildedir [22]:
a) Seçilecek arazinin eğimi,
b) Seçilecek arazinin özellikleri,
c) Seçilecek araziye ulaşım yolu olup olmadığ
ç) DSİ sulama programı dışında olması,
d) Tarım dişı statüsünde olması,
e) Maden arazisi statüsünde olmaması,
f) Arazinin toprak türü,
g) Çevresinde gölgelenmeye sebebiyet verecek engel bulunmaması,
g) Dağıtım şebekesine yakınlığ 1 , 
h) Güney cepheye dönük olması

1) Bölgedeki hava şartlarının uygunluğu (aşırı rüzgâr, kar, sis ve toza maruz kalmaması)

Van ilinin ilçeleri gerek yıllık güneşlenme süreleri gerek yukarıda belirtilen kriterler bakımından Google Earth üzerinden incelenmiştir. Özellikle güney cepheli ve eğimli arazi seçilmeye çalışılmış ve ulaşım yolu ile trafo merkezine yakınlığ 1 da gözetilmiştir. 1 MW GES yatırımı için yaklaşık 20 dönüm $\left(20,000 \mathrm{~m}^{2}\right)$ arazi gerekmekte olup üzerinde GES yatırımı yapılabilecek bu büyüklükte arazi bakımından Edremit ilçesi uygun görülmüştür. Proje için seçilen arazi Şekil 3 (a)'da gösterilmiş olup tamamı mera bölgesinde yer almakta ve mutlak tarım arazisi statüsünde bulunmamaktadır. Bu bakımdan GES kurulumu için İl Çevre ve Şehircilik Genel Müdürlüğünden mera faaliyeti amaç dışı kullanım izni alınması gerekmektedir. Ayrıca seçilen arazinin bitişiğinden D300 Bitlis-Van karayolu geçmektedir. Proje arazisi 38.364 Enlem (Latitude) ve 43.209 Boylam (Longitude) koordinatlarında yer almakta olup büyüklüğ̈̈ $20,000 \mathrm{~m}^{2}$ dir.
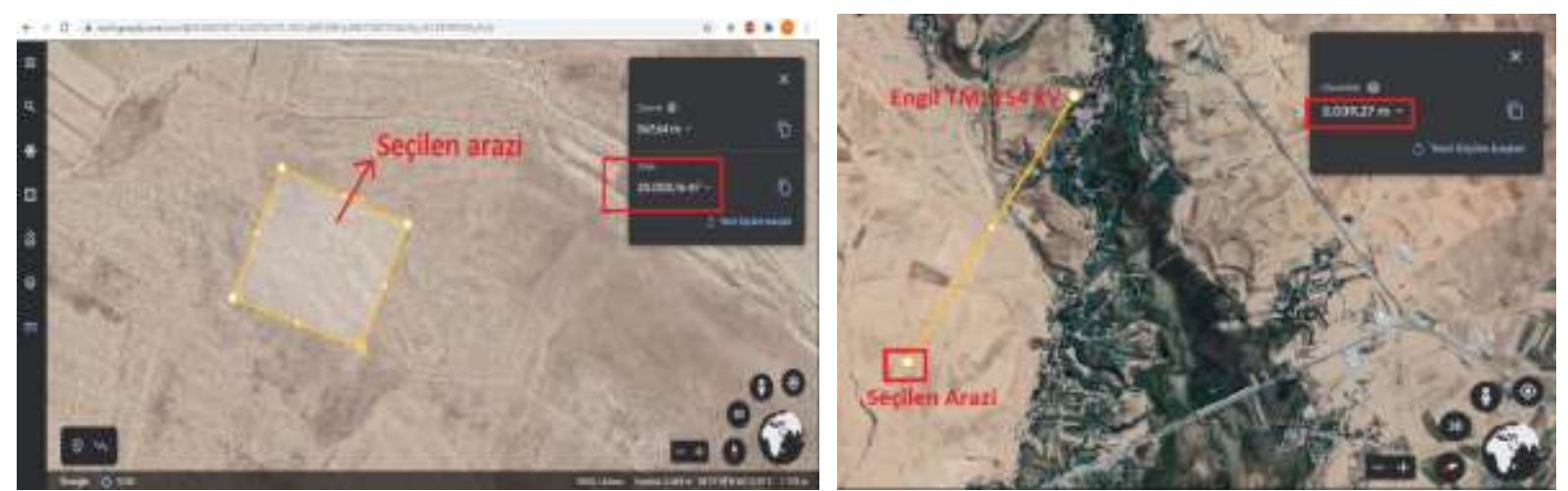

Şekil 3. (a) Seçilen arazinin görünümü (b) Seçilen arazi ile Engil TM arasındaki mesafe

$\mathrm{Bu}$ çalışmada, GES yatırımının lisanslı üretim faaliyeti kapsamında yapılacağı ve üretilen elektriğin tamamının şebekeye verileceği kabul edilmiştir. Bu bağlamda, yatırımın yapılacağı arazinin yakınlarında bulunan projenin bağlantısının yapılabileceği trafo merkezleri için TEİAŞ ve Vangölü Elektrik Dağıtım A.Ş. internet sayfaları incelenmiş olup santral sahasına yaklaşık $3 \mathrm{~km}$ uzaklıkta Engil TM bulunduğu görülmüştür. Engil TM ile seçilen arazi arasındaki mesafe Şekil 3 (b)'de gösterilmiştir. Yatırımı yapılan GES projesinin 1 MW Kurulu güce sahip olması ve 10 MW'tan az olması dolayısıyla orta gerilimden sisteme bağlantısının yapılması uygun olacaktır. Bu bakımdan, 1 MW GES projesinin bağlantısının "Engil TM’nin OG barasına" yapılacağı varsayılmıştır.

\subsection{PVGIS ile enerji hesaplamalarının yapılması}

Güneş enerji sistemlerinin analizinin, simülasyonunun ve enerji hesaplamalarının yapılmasında PVSOL, PVsyst, Polysun, Helioscope, PVGIS gibi programlar kullanılmaktadır [23]. Bu çalışmada, dünya üzerindeki herhangi bir koordinat bilgisine göre meteorolojik verilere sahip olan ve panel çeşitlerine göre elektrik üretim miktarı ile radyasyon miktarlarının hesaplanması gibi çeşitli analizlerin yapılabildiği PVGIS çevrim içi veri tabanı kullanılmıştır.

PVGIS programında seçilen arazinin koordinatlarına göre $\mathrm{m}^{2}$ başına düşen aylık radyasyon miktarları ile yıllık elektrik üretim miktarları hesaplanmıştır. PVGIS internet sayfasında "Performance of Grid-Connected PV (Şebekeye bağll fotovoltaik güneş enerji santrali performansı)" modülü kullanılarak seçilen arazinin koordinatları ile fotovoltaik panel özellikleri girilmiştir. Veri giriş ekranına ilişkin bilgiler Şekil 4'te gösterilmiş̧ir. GES projesi için monokristal fotovoltaik güneş panelleri seçilmiştir. Elde edilen sonuçlar özet halinde Şekil 5'te, aylık elektrik üretim miktarları Şekil 6' da ve aylık radyasyon miktarları Şekil 7'de sunulmuştur. 


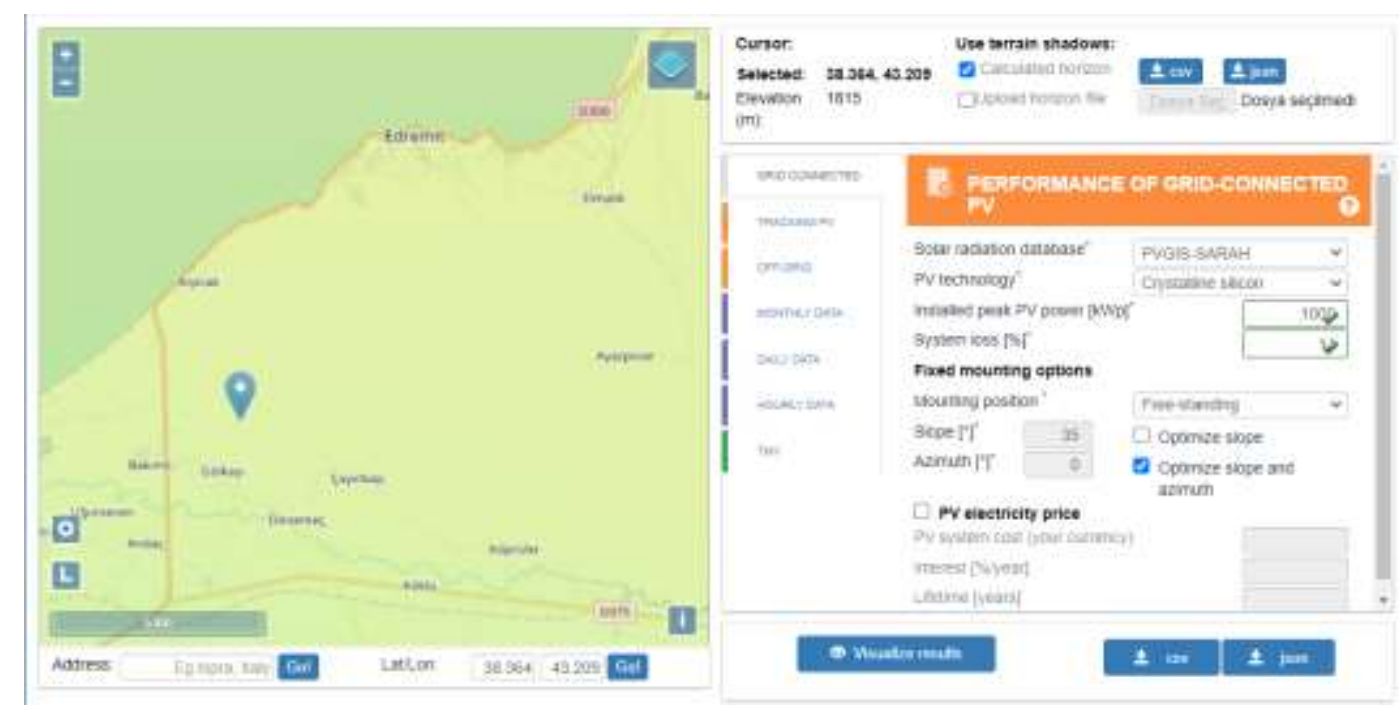

Şekil 4. PVGIS veri giriş ekran görüntüsü

\section{Performance of grid-connected PV}

PVGIS-5 estimates of solar electricity generation:

\begin{tabular}{|c|c|}
\hline Provided input: & \\
\hline Latitudeilongtude & $=38,364,43209$ \\
\hline Horizon: & Calculated \\
\hline Database used & PVGIS-SARAH \\
\hline PV techinology: & Crystaline slicor \\
\hline PV instaled & $1000 \mathrm{kWp}$ \\
\hline System loss: & $14 \%$ \\
\hline
\end{tabular}

Simulation outputs
Slope angle:
Azimuth angle:
Yearly PV energy production:
Yearly in-plane imadation:
Year-to-year variability:
Changes in output due to:
Angle of incidence
Spectral effects:
Temperature and low irradiance
Total loss:

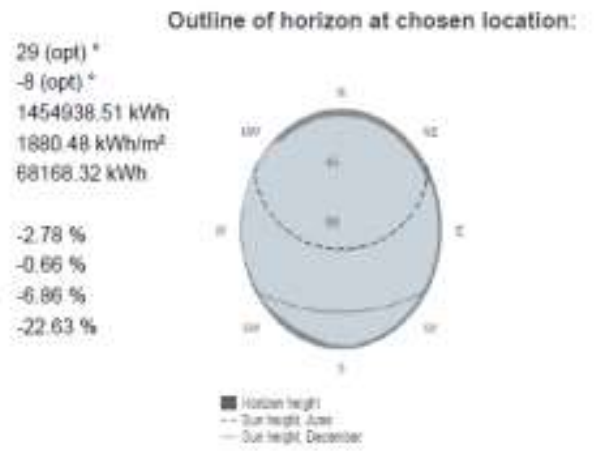

Şekil 5. Seçilen arazi için PVGIS analiz sonuçlarının özet raporu

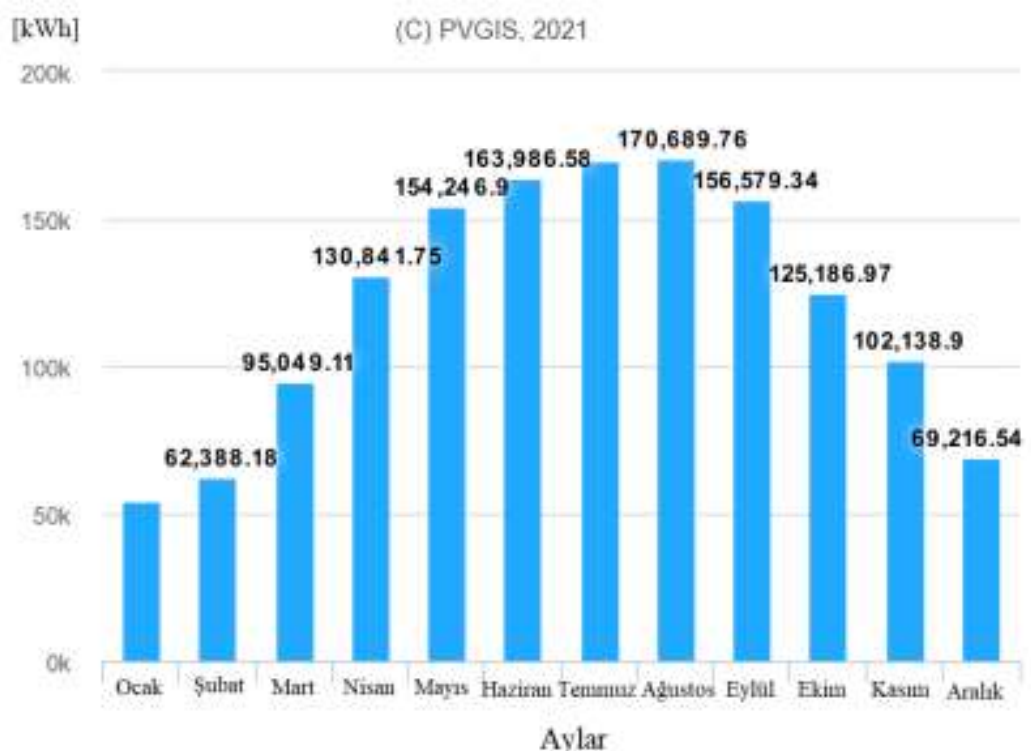

Şekil 6. Seçilen arazi için aylık elektrik üretim miktarları $(\mathrm{kWh})$ 


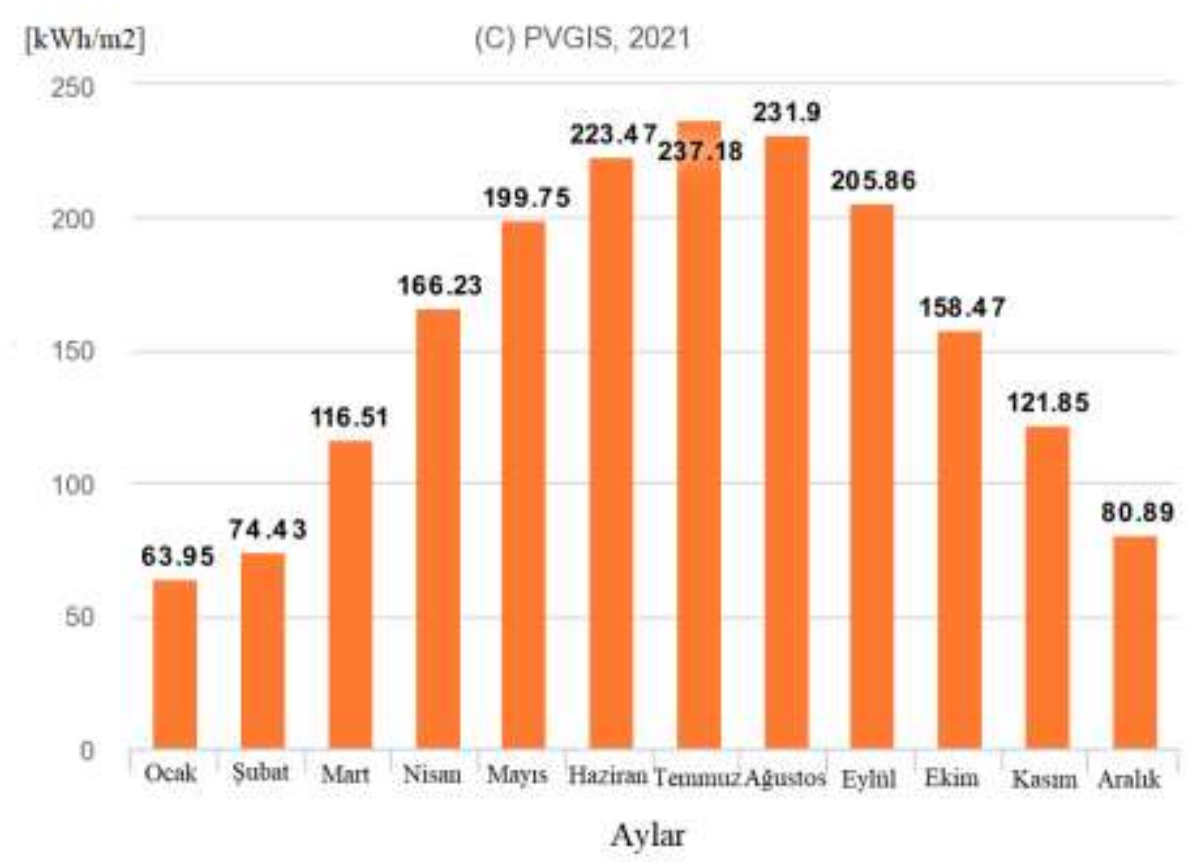

Şekil 7. Seçilen arazi için $\mathrm{m}^{2}$ başına düşen aylık radyasyon miktarları $\left(\mathrm{kWh} / \mathrm{m}^{2}\right)$

Şekil 5'te görüleceği üzere, PVGIS'te yapılan analiz sonucunda yıllık elektrik üretim miktarı $1,454,938.51 \mathrm{kWh}$ olarak hesaplanmıştır. Fotovoltaik güneş panellerinin ekonomik ömrü boyunca (2025 süre) yıllar içerisindeki bozulmaya bağlı olarak her yıl çıkış gücünde lineer bir düşüş yaşanacağı varsayılarak ekipman garantisi sunulmaktadır. Bu çerçevede, tasarımda panel veriminin her y1l \%0.7 azalacağı kabul edilmiş ve panellerin 25 yıllık ekonomik ömrü boyunca santralden elde edilecek elektrik üretim miktarları hesaplanarak Tablo 1'de gösterilmiştir.

Tablo 1. Santralde 25 yll boyunca üretilecek elektrik enerjisi miktarları $(\mathrm{kWh})$

\begin{tabular}{cccccc}
\hline Y11 & $\begin{array}{c}\text { Panel } \\
\text { Verimi }\end{array}$ & $\begin{array}{c}\text { Elektrik Ürt. Mik. } \\
(\mathrm{kWh})\end{array}$ & Y11 & $\begin{array}{c}\text { Panel } \\
\text { Verimi }\end{array}$ & $\begin{array}{c}\text { Elektrik Ürt. Mik. } \\
(\mathrm{kWh})\end{array}$ \\
\hline 1 & $\% 100.0$ & $1,454,938.51$ & 14 & $\% 90.9$ & $1,327,959.62$ \\
\hline 2 & $\% 99.3$ & $1,444,753.94$ & 15 & $\% 90.2$ & $1,318,663.90$ \\
\hline 3 & $\% 98.6$ & $1,434,640.66$ & 16 & $\% 89.5$ & $1,309,433.26$ \\
\hline 4 & $\% 97.9$ & $1,424,598.18$ & 17 & $\% 88.8$ & $1,300,267.22$ \\
\hline 5 & $\% 97.2$ & $1,414,625.99$ & 18 & $\% 88.1$ & $1,291,165.35$ \\
\hline 6 & $\% 96.5$ & $1,404,723.61$ & 19 & $\% 87.4$ & $1,282,127.20$ \\
\hline 7 & $\% 95.8$ & $1,394,890.54$ & 20 & $\% 86.7$ & $1,273,152.30$ \\
\hline 8 & $\% 95.1$ & $1,385,126.31$ & 21 & $\% 86.0$ & $1,264,240.24$ \\
\hline 9 & $\% 94.4$ & $1,375,430.43$ & 22 & $\% 85.3$ & $1,255,390.56$ \\
\hline 10 & $\% 93.7$ & $1,365,802.41$ & 23 & $\% 84.6$ & $1,246,602.82$ \\
\hline 11 & $\% 93.0$ & $1,356,241.80$ & 24 & $\% 83.9$ & $1,237,876.60$ \\
\hline 12 & $\% 92.3$ & $1,346,748.10$ & 25 & $\% 83.2$ & $1,229,211.47$ \\
\hline 13 & $\% 91.6$ & $1,337,320.87$ & TOPLAM & $\mathbf{3 3 , 4 7 5 , 9 3 1 . 8 9}$ \\
\hline
\end{tabular}

Tablo-1'de hesaplanan elektrik üretim miktarları; mevsimsel değişikliklere, kışın yoğun yaşanıp yaşanmamasına, panellerin bakım ve onarımının sık ve düzenli yapılmasına, kullanılan güneş panellerinin çeşidi ve kalitesine, panel yüzeylerinin sıklıkla temizlenmesine bağlı olarak değişiklik gösterebilmektedir. Bu nedenle santralde üretilecek elektrik enerjisi miktarlarında yıllar içerisinde ciddi 
oranda düşüş yaşanmaması için ekipman bakım, onarım ve değişiminin düzenli aralıklarla yapılması oldukça önemli bir husustur.

\subsection{GES yatırımının fayda ve maliyet unsurları}

5346 sayılı Yenilenebilir Enerji Kaynaklarının Elektrik Enerjisi Üretimi Amaçlı Kullanımına İlişkin Kanunun eki I sayılı cetvele göre, güneş enerjisine dayalı lisanslı elektrik üretim tesislerinin 30/06/2021 tarihine kadar işletmeye girmeleri halinde, bu santrallerden üretilen elektrik enerjisi için 10 y1l boyunca YEK Destekleme Mekanizması (YEKDEM) kapsamında 13.3 ABD Doları cent/kWh fiyattan alım garantisi sağlanmaktadır [24]. Yatırımı yapılan $1 \mathrm{MW}$ güneş enerji santralinin işletmeye girdiği tarihten itibaren ilk 10 yıl boyunca santralde üretilen elektriğin YEKDEM kapsamında 13.3 ABD Doları cent/kWh fiyattan satılacağ kabul edilmiş, geriye kalan 15 yıl boyunca ise serbest piyasada son beş yılın (2016-2020) ortalama piyasa takas fiyatı (4.5 ABD Doları cent/kWh) [25] üzerinden satışının yapılacağı varsayılmıştır.

Bir diğer fayda kalemi ise yatırımın hurda değeridir. Hurda değeri, bir yatırımın ekonomik ömrü sonundaki satış değeri olarak tanımlanmakta olup tüm makine ve ekipmanların kullanım sonrası değerini ifade eder [26]. 1 MW GES yatırımının hurda değerinin ekipman maliyetlerinin \%30'u olacağı kabul edilmiştir.

Projenin maliyet unsurları ise arazi bedeli, kullanılacak ekipman maliyetleri, diğer ilk yatırım maliyetleri ile yıllara bağlı değişen işletme ve bakım maliyetleri şeklinde sınıflandırılmıştır.

Projenin kurulacağı arazinin satın alınacağı varsayılmıştır. Seçilen arazinin bulunduğu bölgedeki arazi fiyatları çeşitli arazi satış platformları ile Van ili Edremit Belediyesi internet sayfasından araştırılmış olup GES kurulumuna uygun $\mathrm{m}^{2}$ başına ortalama arazi fiyatının $20 \mathrm{TL} / \mathrm{m}^{2}$ olduğu görülmüştür. Proje için seçilen arazi $20,000 \mathrm{~m}^{2}$ olduğundan arazi bedeli $400,000 \mathrm{TL}$ ve ABD Doları cinsinden 26 Şubat 2021 tarihli satış bazlı dolar kuru USD/TRY 7.4 [27] olarak kabul edildiğinde 54,054 ABD Doları olarak hesaplanmıştır.

Güneş enerji santrali için temel unsurlar olan solar panel, invertör, montaj sistemleri, solar kablolar vb. ekipmanlar hakkında güneş enerji sistemlerinin projelendirilmesi, satış1 ve kurulumu ile ilgili çeşitli firmalarla görüşülerek 2021 y1lı için güncel fiyat bilgileri alınmıştır. Edinilen bilgiler çerçevesinde, fotovoltaik güneş paneli ve invertör için 2021 yılı satış fiyatları alınmış olup diğer ekipmanlar için ortalama fiyat bilgileri kullanılmıştır. Kurulacak ekipmanların tamamının Türkiye'de üretildiği kabul edilerek nakliye maliyeti ayrı bir kalem olarak diğer yatırım maliyetleri altında değerlendirilmiştir.

1 MW GES kurulumu için gerekli ekipmanlar ve ABD Doları cinsinden fiyatları Tablo 2'de gösterilmiştir.

Tablo 2. 1 MW GES kurulumu için gerekli ekipman ve fiyatları [28, 29]

\begin{tabular}{|c|c|c|}
\hline Ekipman & Açılama & Tutar (ABD Doları) \\
\hline $\begin{array}{l}\text { Fotovoltaik Güneş Paneli } \\
\text { (Monokristal silikon yapılı) }\end{array}$ & $\begin{array}{l}\text { 2,500 adet } 400 \text { Watt, } 47.95 \text { V LEXRON } \\
\text { marka, Monokristal } 72 \text { hücreli }\end{array}$ & 300,000 \\
\hline İnvertör & 200 adet, $5 \mathrm{~kW}$, GoodWe marka & 45,000 \\
\hline $\begin{array}{l}\text { Kontrol ve İzleme Sistemi } \\
\text { (SCADA) }\end{array}$ & 4 adet & \multirow{9}{*}{200,000} \\
\hline Sabit Montaj Yapısı & 1 set & \\
\hline DC Kablolama & $21,000 \mathrm{~m}$ & \\
\hline AC Kablolama & $3,750 \mathrm{~m}$ & \\
\hline Toplama Panosu & $1 \mathrm{set}$ & \\
\hline Tel Çit ve Dikenli Tel & $750 \mathrm{~m}$ & \\
\hline Peyzaj ve Toprak İşleri & $1,500 \mathrm{~m}^{3}$ & \\
\hline $\begin{array}{l}\text { Paratoner ve Topraklama } \\
\text { Sistemleri (Aktif paratoner başlı̆̆ }, \text {, } \\
6 \mathrm{~m} \text { direk, } 2 \times 50 \mathrm{~mm}^{2} \text { bakır iniş } \\
\text { iletkeni, } 3 \mathrm{~m} \text { boru) }\end{array}$ & 1 set & \\
\hline $\begin{array}{l}\text { Video Güvenlik ve Kamera } \\
\text { Sistemleri ( } 8 \text { kamera (Dış mekân, } \\
\text { analog HD, NVR kayıt cihazı (4 } \\
\text { TB HDD), 24" ekran, kablolama) }\end{array}$ & 1 set & \\
\hline
\end{tabular}




\begin{tabular}{|c|c|c|}
\hline $\begin{array}{l}\text { Trafo, Köşk ve Hücreler, ENH } \\
\text { İşleri }\end{array}$ & 1 set & \\
\hline Çift Yönlü Sayaç & 1 adet & \\
\hline Tek yönlü sayaç (3 fazlı) & 1 adet & \\
\hline Kablo Tava Sistemleri & $800 \mathrm{~kg}$ & \\
\hline Solar kablo (kırmızı ve mavi) & 1x6 mm² PVI1-F solar kablo $6000 \mathrm{~m}$ & \\
\hline $5 \times 16 \mathrm{~mm}^{2} \mathrm{NYY}$ & $400 \mathrm{~m}$ & \\
\hline $\begin{array}{l}3 \times 35 / 16 \mathrm{~mm}^{2} \text { XLPE kablo (36 } \\
\mathrm{KV})\end{array}$ & $3000 \mathrm{~m}$ & \\
\hline $\begin{array}{l}\text { 35’lik ve } 16 \text { 'lı XLPE kablo } \\
\text { başlığ } 1\end{array}$ & 426 ve 142 adet & \\
\hline $\mathrm{OG}+\mathrm{AG}$ harici pano & 70 adet & \\
\hline $\begin{array}{l}100 \times 10 \mathrm{~mm}^{2} \text { bakır baralı modüler } \\
\text { hücre }\end{array}$ & 1 adet & \\
\hline $\begin{array}{l}1250 \text { A yük ayırıcılı akım ve } \\
\text { gerilim ölçü modüler hücresi }\end{array}$ & 1 adet & \\
\hline $\begin{array}{l}1250 \text { kesicili trafo koruma } \\
\text { modüler hücre }\end{array}$ & 1 adet & \\
\hline $\begin{array}{l}1250 \text { A kesicili giriş çıkış modüler } \\
\text { hücre }\end{array}$ & 1 adet & \\
\hline Beton Köşk & $5 \mathrm{~m}$, çatılı & \\
\hline 10 kVA kuru tip trafo & 71 adet & \\
\hline 4x63 A TMŞ+KAKR (300 mA) & 104 adet & \\
\hline $3 \times 63$ A NH sigorta ve taşıyıcısı & 74 adet & \\
\hline $\begin{array}{l}0,28 \mathrm{kV}, 100 \mathrm{kA} \mathrm{B}+\mathrm{C} \text { parafudur } \\
(\mathrm{AG})\end{array}$ & 71 adet & \\
\hline OG parafudur & 1 takım & \\
\hline $\begin{array}{ll}\text { Topraklama kazığı }(65 \times 65 \times 7) & 1.5 \\
\text { m uzunluğunda }\end{array}$ & 225 adet & \\
\hline $\begin{array}{l}\text { Galvanizli şerit iletken }(30 \times 3.5 \\
\mathrm{mm})\end{array}$ & $600 \mathrm{~m}$ & \\
\hline $\begin{array}{l}1 \times 16 \mathrm{~mm}^{2} \text { NYAF topraklama } \\
\text { kablosu }\end{array}$ & $500 \mathrm{~m}$ & \\
\hline Fotovoltaik panel konstrüksiyon & 1 sistem & \\
\hline Saha aydınlatma ekipmanları & 1 takım & \\
\hline \multicolumn{3}{|c|}{ Toplam } \\
\hline
\end{tabular}

Tablo-2'de yer verilen ekipman ve teçhizatlar 1 MW GES yatırımlarının tümünde genel olarak yer alması gereken unsurlardan oluşmaktadır. Ancak kurulum yapılacak arazinin yapısına, cephesine, panel çeşidine veya bağlantı karakteristiğine göre farkl1lık gösterebilmektedir.

Santral kurulumu için mühendislik, kurulum ve inşaat (Engineering, Procurement and Construction-EPC Company) firmalarıyla anlaşlabileceği gibi, kurulum, inşaat ve montaj işleri ayrıca bir inşaat firması tarafından da yapılabilmektedir. EPC şirketi, projenin tüm ekipmanlarının temininden santralin işletmeye alındığı ana kadar anahtar teslim kurulumunu gerçekleştirir. Bu çalışmada, kurulum ve montaj işlemlerinin ayrı bir inşaat firması tarafından yapılacağı varsayılarak ekipman maliyetleri kurulum maliyetlerinden ayrı olarak dikkate alınmıştır. Ekipman maliyetleri dışındaki diğer ilk yatırım maliyet unsurları, santral kurulumunu gerçekleştiren şirketler ile yapılan görüşmeler ve pazar araştırması neticesinde belirlenerek Tablo 3'te gösterilmiştir. Lisanslı GES yatırımı için Elektrik Piyasası Lisans Yönetmeliğine göre anonim veya limited şirket kurulması zorunludur. Ayrıca santralin SCADA izleme sisteminin de içerisinde yer alacağ idari bina ve otopark, bahçe, yemekhane vb. gereksinimler için sosyal alan inşası gerekmekte olup bu unsurlara diğer ilk yatırım maliyetleri içerisinde yer verilmiştir. Buna ilaveten, Elektrik Piyasası Lisans Yönetmeliği uyarınca inşaat aşamasına geçmeden önce gerekli izinlerin alınması için verilen önlisans süresi içerisinde tamamlanması gereken imar planlarının onaylatılması, ÇED kararının alınması, proje onayı gibi idari işlemler için oluşacak maliyet kalemlerine de Tablo-3'te ayrıca yer verilmiştir. Santralin ulusal şebekeye bağlantısını sağlayacak olan Engil TM'ye kadar olan 3 km'lik mesafedeki enerji nakil hattının (ENH) Elektrik Piyasası Bağlantı ve Sistem Kullanım Yönetmeliği kapsamında dağıtım şirketi Vangölü Elektrik 
Dağıtım A.Ş. tarafindan yapılacağı ve şirket tarafindan sadece bağlantı ve sistem kullanım bedeli ödeneceği varsayılmış, bu nedenle bağlantı hattı tesisi diğer yatırım maliyetleri arasında sayılmamıştır.

Tablo 3. Diğer ilk yatırım maliyet unsurları

\begin{tabular}{|l|c|}
\hline \multicolumn{1}{|c|}{ Maliyet Unsuru } & Tutar (ABD Doları) \\
\hline Proje ve fizibilite raporu hazırlama & 2,000 \\
\hline $\begin{array}{l}\text { Santral sahasına ve santral içi ulaşım yollarının inşası, inşaat, } \\
\text { nakliye, montaj ve kurulum maliyetleri }\end{array}$ & 10,000 \\
\hline Şirket kurulum maliyeti & 4,000 \\
\hline İdari bina ve sosyal alan inşası & 5,000 \\
\hline $\begin{array}{l}\text { İdari süreçlerle ilgili masraflar (lisans alma bedeli, proje onay } \\
\text { ve kabul işlemleri, imar ve ÇED kararı) }\end{array}$ & 3,000 \\
\hline Toplam & $\mathbf{2 4 , 0 0 0}$ \\
\hline
\end{tabular}

İlk yatırım maliyetlerinin yanı sıra, santralin işletiminde yatırımın ekonomik ömrü boyunca her yıl tekrar eden işletme ve bakım masrafları oluşmaktadır. Bu maliyet unsurlarına ilişkin açıklamalar ile tutarları Tablo 4 'te gösterilmiş̧tir. Söz konusu maliyetlerin, yıllık enflasyon oranı ile kurdaki değişmeleri dengeleyecek şekilde her yıl \%3 oranında artacağı varsayılmıştır.

Tablo 4. Yıllık işletme ve bakım maliyet unsurları

\begin{tabular}{|c|c|c|}
\hline Maliyet Unsuru & Açıklama & Tutar (ABD Dolar1) \\
\hline Yıllık işçilik giderleri & $\begin{array}{l}\text { Santral Van ilinde kurulacağı için kış } \\
\text { mevsiminde yoğun kar ve tozlanma } \\
\text { yaşanabilecek, güvenlik/arıza durumları } \\
\text { için daha fazla güvenlik personeli } \\
\text { çalıştırılması gerekebilecektir. Bu } \\
\text { bağlamda en az } 2 \text { mühendis ve } 3 \text { teknik } \\
\text { eleman istihdam edileceği varsayılmıştır. }\end{array}$ & 10,000 (1. y1l maliyeti) \\
\hline $\begin{array}{l}\text { İşletme, bakım ve onarım } \\
\text { giderleri }\end{array}$ & $\begin{array}{l}\text { Santralde arıza ve fazla miktarda verim } \\
\text { düşümü yaşanmaması için her yıl bakım } \\
\text { ve onarım yapılacağı düşünülerek yıllık } \\
\text { maliyet olarak hesaplanmıştır. }\end{array}$ & 5,000 (1. y1l maliyeti) \\
\hline GES sigorta bedeli & $\begin{array}{l}\text { Yangın, hırsızlık, doğal afetler, terör, } \\
\text { kötü niyetli hareketler, elektronik cihaz } \\
\text { ve makine kırılmasına bağlı kâr } \\
\text { kayıplarını önlemek amacıyla } \\
\text { santrallerde "all risk inşaat sigortası" } \\
\text { yapılması zorunludur. Bu maliyet kalemi } \\
\text { de yıllık olarak hesaplanmıştır. }\end{array}$ & 4,000 (1. y1l maliyeti) \\
\hline Dağıtım sistem kullanım bedeli & $\begin{array}{l}\text { EPDK tarafindan yayımlanan } 2021 \text { yılı } \\
\text { 1. çeyrek tarife tablosuna göre üreticiler } \\
\text { için veriş yönünde tek terimli dağıtım } \\
\text { tarifesi } 2.722 \mathrm{kr} / \mathrm{kWh} \text { 'dir [30]. Bir yıllık } \\
\text { ödenmesi gereken bedel, 1. yıl elektrik } \\
\text { üretim miktarına göre hesaplanmıştır. } \\
\text { Tarifelerdeki yılllı artışı enflasyon } \\
\text { oranının dengeleyeceği varsayılmıştır. }\end{array}$ & 5,351 (1. y1l maliyeti) \\
\hline $\begin{array}{l}\text { Ticari, teknik ve şirket faaliyetine } \\
\text { bağlı işlem maliyetleri }\end{array}$ & $\begin{array}{l}\text { Şirketin santralin işletiminden ve elektrik } \\
\text { üretim faaliyetinden kaynaklı çeşitli } \\
\text { ticari ve teknik maliyetlerini } \\
\text { kapsamaktadır. }\end{array}$ & 2,000 (1. y1l maliyeti) \\
\hline Diğer giderler & $\begin{array}{l}\text { Beklenmedik durumlara bağlı santral } \\
\text { işletiminde y1llık ilave maliyetler } \\
\text { oluşabileceği kabul edilerek bu başlık } \\
\text { altında değerlendirilmiştir. }\end{array}$ & 2,500 (1. y1l maliyeti) \\
\hline \multicolumn{2}{|l|}{ 1. Yil Toplam } & 28,851 (1. yıl maliyeti) \\
\hline
\end{tabular}




\subsection{Finansal analizde kullanılan yöntemler}

Projelerin finansal açıdan değerlendirilmesi ve yatırım kararının alınmasında yararlanılan statik (paranın zaman değerini dikkate almayan) ve dinamik (paranın zaman değerini dikkate alan) yöntemler mevcuttur [31]. Bu çalı̧̧mada statik yöntemlerden geri ödeme süresi (GÖS) yöntemi; dinamik yöntemlerden ise net bugünkü değer (NBD), iç kârlılık (verimlilik) oranı (IKO) ve fayda/masraf oranı (FMO) yöntemleri kullanılarak yatırımın finansal açıdan kârlılığı değerlendirilmiştir.

\subsubsection{Geri ödeme süresi yöntemi}

Bu yönteme göre yatırımın geri ödeme süresi, yıllık net kâr tutarları toplamının ilk yatırım maliyetlerine eşitlendiği ve pozitif net getiri elde edilmeye başlandığı yıl olarak hesaplanmaktadır [31]. Yıllar itibarıyla toplanan yıllık kazanç tutarlarının ilk yatırım maliyetini karşıladığı yıl yatırımın geri ödeme süresini göstermektedir.

$\mathrm{Bu}$ çalışmada yıllık amortisman payı, güneş enerji santralinde kullanılan ekipman verimi yıllık $\% 0.7$ oranında azalacak şekilde hesaplanarak dolaylı olarak yıllık kazanç tutarında düşüş şeklinde hesaplamaya dâhil edilmiştir. GES'lerde ortalama 5-7 yıllık geri ödeme süreleri normal olarak kabul edilmekle birlikte 2020 yılı itibarıyla bu sürenin 4 yıla kadar indiği görülmektedir [32].

$G O ̈ S=\frac{\text { Yatırım tutarı }}{\text { Yıllık ortalama net kâr }}$

\subsubsection{Net bugünkü değer yöntemi}

Paranın zaman değerini dikkate alan bu yönteme göre net bugünkü değer (NBD), yatırımın ekonomik ömrü boyunca sağladığı kazançların bugünkü değerleri toplamı ile yatırım maliyetlerinin bugünkü değerleri toplamı arasındaki farkı ifade etmekte olup aşağıdaki formüle göre hesaplanmaktadır [26].

$N B D=\sum_{t=0}^{n} \frac{F_{t}}{(1+i)^{t}}-\sum_{t=0}^{n} \frac{M_{t}}{(1+i)^{t}}$

$\mathrm{Bu}$ formülde geçen,

$\mathrm{t} \quad$ : Yatırım süresi içerisindeki ilgili takvim yılını,

i : Kabul edilen iskonto oranın,

n : Yatırımın ekonomik ömrünü,

$\mathrm{F}_{\mathrm{t}} \quad$ : t. yıldaki kazanç tutarını,

$\mathrm{M}_{\mathrm{t}} \quad$ : t. yıldaki maliyet tutarını

göstermektedir. NBD’nin pozitif bir değer olarak hesaplanması yatırımın kârlı olduğunu, negatif olması elde edilen kazançların yatırım için katlanılan maliyetleri karşılamadığını göstermekte; NBD'nin 0 olması ise yatırım sonucunda ne kâr ne de zarar elde edildiğini yani kazançların toplam maliyetlere denk geldiği durumu temsil etmektedir [26]. Bu çalışmada, yatırımdan beklenen kâr payı (kabul edilebilir iskonto oranı) \%10 olarak alınmıştır.

\subsection{3. İç kârlılık (verimlilik) oranı yöntemi}

İç karlılık oranı, bir yatırımın fayda ve masraf unsurlarına göre hesaplanan net bugünkü değerini sıfıra eşitleyen iskonto oranı şeklinde tanımlanmaktadır. Diğer bir deyişle, yatırımın ekonomik ömrü boyunca getirilerinin bugünkü değerleri toplamını maliyetlerinin bugünkü değerleri toplamına eşitleyen iskonto oranıdır [26]. İç kârlılık oranı, net bugünkü değer yönteminde belirtilen formül ve kısaltmalar doğrultusunda aşağıdaki formüle göre hesaplanmaktadır.

$\sum_{t=0}^{n} \frac{F_{t}}{(1+r)^{t}}=\sum_{t=0}^{n} \frac{M_{t}}{(1+r)^{t}}$ 
Burada iskonto oranı (i) yerine fayda ve masrafların bugünkü değerlerini eşitleyen iç karlılık oranını temsil eden "r" kullanılır ve faydaların bugünkü değerini masrafların bugünkü değerine eşitleyecek şekilde deneme yanılma yoluyla bulunur [31]. Hesaplanan iç kârlılık oranından daha yüksek orandaki iskonto oranlarında yatırımın NBD'si negatife dönerken daha düşük iskonto oranlarında yatırımın NBD'si artmakta yani yatırım daha kârlı hale gelmektedir. Bu bağlamda, İKO'nun yatırımcı tarafindan kabul edilebilir iskonto oranından daha yüksek çıkması durumunda yatırım kararı verilmesi uygun olup tam tersi durumda ise yatırım kârlı olmayacağından yatırım kararının reddedilmesi gerekmektedir.

\subsubsection{Fayda/Masraf oranı yöntemi}

Bu yöntemde fayda/masraf oranı (FMO), yatırımın ekonomik ömrü boyunca getiri tutarlarının bugünkü değerleri toplamının yatırım maliyetlerinin bugünkü değerleri toplamına bölünmesi suretiyle aşağıda verilen formüle göre hesaplanır [31].

$F M O=\frac{\sum_{t=0}^{n} \frac{F_{t}}{(1+i)^{n}}}{\sum_{t=0}^{n} \frac{M t}{(1+i)^{n}}}$

Fayda/masraf oranının 1'den büyük veya 1'den küçük olması durumlarına göre değerlendirme yapılır. FMO 1'den büyük ise yatırım kârlı olarak görülmekte, 1'den küçükse yatırım kararının reddedilmesi gerekmektedir. FMO'nun 1'e eşit çıkması durumu yatırımın ekonomik ömrü boyunca ne kâr ne zarar getireceğini yani toplam kazançların toplam maliyetlere denk geleceğini göstermektedir. Yatırımcı, kabul edilebilir iskonto oranı esas alınarak hesaplanan FMO'ya göre yatırımı gerçekleştirme veya gerçekleştirmeme kararı verir.

\subsubsection{Yatırımın öz sermaye veya kredi ile yapılması}

Günümüzde yenilenebilir enerji yatırımları tamamen öz sermaye ile yapılabileceği gibi kısmi veya tamamen kredi ile de yapılabilmektedir. Dolayısıyla bu çalışmada, yatırımın tamamen öz sermaye ile veya tamamen kredi ile karşılandığı iki farklı durum için GES yatırımının yukarıda belirtilen yöntemlere göre finansal analizi yapılarak sonuçlar karşılaştırılmıştır.

İlk yatırım maliyetlerinin öz sermaye ile karşılanması halinde, yıllık işletme ve bakım masrafları haricindeki ilk yatırım maliyetleri yatırımın başında harcanmaktadır. Yatırımın kredi ile yapılacak olması halinde ise hesaplanan ilk yatırım maliyeti tutarının, Türkiye Sürdürülebilir Enerji Finansman Programının (TurSEFF) yenilenebilir enerji kredisi programı kapsamında 1 MW GES yatırımı için 10 yıl süreli yıllık \%5 faiz oranıyla alınan kredi ile karşılanacağı kabul edilmiştir [26, 33]. 10 yıl süreli alınacak kredinin yıllık eşit tutardaki geri ödeme miktarı aşağıdaki formüle göre hesaplanmıştır [26].

$P=A x \frac{(1+i)^{n} x i}{(1+i)^{n}-1}$

$\mathrm{Bu}$ formülde geçen,

P : 10 yıl eşit taksitle çekilen kredinin geri ödeme taksit tutarını,

A : Kredi çekilen ilk yatırım maliyeti tutarını,

n : Kredi geri ödeme süresini,

i : Kredi yıllık faiz oranını

ifade etmektedir. İlk yatırım maliyetleri toplamı olan 623,054 ABD Doları tutarında çekilen TurSEFF kredisi için yıllık geri ödeme taksit tutarı 80,688 ABD Doları olarak hesaplanmıştır. Kredi geri ödeme taksitlerinin yatırımın ilk yılı sonunda başlayacağ kabul edilmiştir. 


\subsection{Finansal analizde yapılan kabuller}

Bu çalışma kapsamında, Van ili Edremit ilçesinde yapılması planlanan 1 MW lisanslı GES yatırımının finansal analizinde ve kurulum aşamasında maliyete etki edecek hususlara ilişkin yapılan kabuller Tablo 5 'te gösterilmiştir.

Tablo 5. GES kurulumunda yapilan kabuller

\begin{tabular}{|c|c|}
\hline Santralin kurulu gücü & $1 \mathrm{MW}$ \\
\hline Santralin faaliyet türü & 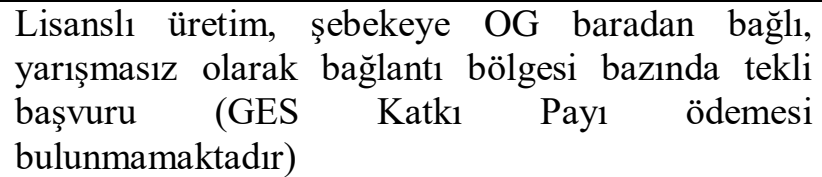 \\
\hline Santralin ekonomik ömrü & 25 y1l \\
\hline Santralde kullanılan güneş paneli türü & $400 \mathrm{kWp}, 72$ hücreli, monokristal \\
\hline Yatırımın hurda değeri & Doğrudan yatırım (ekipman) maliyetinin \%30’u \\
\hline $\begin{array}{l}\text { Santralin güç değerinde (veriminde) yıllık } \\
\text { azalma oranı }\end{array}$ & $\% 0.7$ \\
\hline Finansal analizde kullanılan para birimi & ABD Dolar1 \\
\hline Finansal analizde kullanılan yöntemler & $\begin{array}{l}\text { Net bugünkü değer } \\
\text { İç kârlılık oranı } \\
\text { Fayda/Masraf oranı } \\
\text { Geri ödeme süresi }\end{array}$ \\
\hline Elektrik alım fiyatı & $\begin{array}{l}\text { İlk } 10 \text { y1l: } 13.3 \text { ABD Dolar1 cent } / \mathrm{kWh} \\
\text { 11.-25. y1l: Son } 5 \text { y1lın Piyasa Takas Fiyat1 } \\
\text { ortalamas1 olan } 4.5 \text { ABD Doları cent/kWh }\end{array}$ \\
\hline Değişken maliyetlerin yıllık artış oranı & $\% 3$ \\
\hline İskonto oranı & $\% 10$ \\
\hline Kredi seçeneği ve faiz oran 1 & $\begin{array}{l}\text { TurSEFF Yenilenebilir Enerji Kredisi, } 10 \text { yıl eşit } \\
\text { taksitle geri ödemeli, yıllık \%5 faiz oranı }\end{array}$ \\
\hline Santral sahasına ulaşım yolları & $\begin{array}{l}\text { Santralin kurulacağı arazinin bitişiğinden D300 } \\
\text { Bitlis-Van karayolu geçmektedir, bu bakımdan } \\
\text { gerekli teçhizatın santrale taşınmasında ulaşımın } \\
\text { elverişli olduğu ancak karayolunu santral sahasına } \\
\text { bağlayan yollarda küçük çaplı iyileştirme yapılması } \\
\text { gerektiği kabul edilmiş ve diğer ilk yatırım maliyet } \\
\text { unsuru olarak eklenmiştir. }\end{array}$ \\
\hline Arazi yapısının GES kurulumuna uygunluğu & $\begin{array}{l}\text { Santralin kurulacağı arazi güney cepheye dönük olup } \\
\text { arazi yapısının GES inşasına uygun olduğu ve ilave } \\
\text { maliyet oluşturmayacağ kabul edilmiştir. }\end{array}$ \\
\hline Santralin ulusal elektrik şebekesine bağlantısı & $\begin{array}{l}\text { Santralin Engil TM'nin OG barasına bağlanacağı ve } \\
\text { bağlantı için inşa edilmesi gereken } 3 \text { km } \\
\text { uzunluğundaki enerji nakil hattının Elektrik Piyasası } \\
\text { Bağlantı ve Sistem Kullanım Yönetmeliği } \\
\text { kapsamında bölgede görevli dağıtım şirketi Vangölü } \\
\text { Elektrik Dağıtım A.Ş. tarafından tesis edileceği, } \\
\text { şirket tarafindan yalnızca bağlantı ve sistem } \\
\text { kullanım bedeli ödeneceği varsayılmıstır. }\end{array}$ \\
\hline
\end{tabular}

\section{Bulgular ve Tartışma}

1 MW lisanslı ve şebekeye bağlı GES yatırımının öz sermaye ile yapılması durumu ile tamamen kredi ile yapılması durumlarına ilişkin nakit akış diyagramları sırasıyla Tablo 6 ve Tablo 7'de gösterilmiştir. Söz konusu tablolarda, fayda ve masraf tutarları ABD Doları para birimi cinsinden verilmiştir. Nakit akış çizelgelerinde 0 . yıl yatırıma başlandığı yılı temsil etmekte olup 1. yılda elektrik üretimine 
başlanacağ 1 kabul edilmiştir. Tablolarda verilen tutarlar, 25 yıl olarak belirlenen GES yatırımının ekonomik ömrü boyunca, daha önce açılanan kabuller doğrultusunda yıllık elektrik üretim miktarındaki azalma, alım garantisinin sona erdiği 10. yıldan sonraki elektrik enerjisi satış fiyatı, yıllık enflasyon oranındaki artış vb. kabullerine göre ayrı ayrı hesaplanmıştır.

Tablo 6. Yatırımın öz sermaye ile yapılması durumunda nakit akış çizelgesi

\begin{tabular}{|c|c|c|c|c|c|c|c|c|}
\hline \multirow[t]{2}{*}{ Yillar } & \multicolumn{2}{|c|}{ Faydalar } & \multirow{2}{*}{$\begin{array}{c}\text { Faydaların } \\
\text { Bugünkü } \\
\text { Değeri }\end{array}$} & \multicolumn{4}{|c|}{ Masraflar } & \multirow{2}{*}{$\begin{array}{c}\text { Masrafların } \\
\text { Bugünkü Değeri }\end{array}$} \\
\hline & $\begin{array}{c}\text { Yıllık } \\
\text { kazanç }\end{array}$ & $\begin{array}{l}\text { Hurda } \\
\text { Değeri }\end{array}$ & & $\begin{array}{l}\text { Arazi } \\
\text { Bedeli }\end{array}$ & $\begin{array}{c}\text { Ekipman } \\
\text { Maliyetleri }\end{array}$ & $\begin{array}{c}\text { Diğer İlk } \\
\text { Yatırım } \\
\text { Maliyetleri }\end{array}$ & $\begin{array}{l}\text { İşletme ve } \\
\text { Bakım } \\
\text { Maliyetleri }\end{array}$ & \\
\hline 0 & 0 & & & 54,054 & 545,000 & 24,000 & 0 & 623,054 \\
\hline 1 & 193,507 & & 175,915 & & & & 28,851 & 26,228 \\
\hline 2 & 192,152 & & 158,804 & & & & 29,717 & 24,559 \\
\hline 3 & 190,807 & & 143,356 & & & & 30,608 & 22,996 \\
\hline 4 & 189,472 & & 129,412 & & & & 31,526 & 21,533 \\
\hline 5 & 188,145 & & 116,823 & & & & 32,472 & 20,163 \\
\hline 6 & 186,828 & & 105,460 & & & & 33,446 & 18,880 \\
\hline 7 & 185,520 & & 95,201 & & & & 34,450 & 17,678 \\
\hline 8 & 184,222 & & 85,941 & & & & 35,483 & 16,553 \\
\hline 9 & 182,932 & & 77,581 & & & & 36,548 & 15,500 \\
\hline 10 & 181,652 & & 70,035 & & & & 37,644 & 14,513 \\
\hline 11 & 61,031 & & 21,391 & & & & 38,773 & 13,590 \\
\hline 12 & 60,604 & & 19,310 & & & & 39,937 & 12,725 \\
\hline 13 & 60,179 & & 17,432 & & & & 41,135 & 11,915 \\
\hline 14 & 59,758 & & 15,736 & & & & 42,369 & 11,157 \\
\hline 15 & 59,340 & & 14,205 & & & & 43,640 & 10,447 \\
\hline 16 & 58,924 & & 12,824 & & & & 44,949 & 9,782 \\
\hline 17 & 58,512 & & 11,576 & & & & 46,297 & 9,160 \\
\hline 18 & 58,102 & & 10,450 & & & & 47,686 & 8,577 \\
\hline 19 & 57,696 & & 9,434 & & & & 49,117 & 8,031 \\
\hline 20 & 57,292 & & 8,516 & & & & 50,590 & 7,520 \\
\hline 21 & 56,891 & & 7,688 & & & & 52,108 & 7,041 \\
\hline 22 & 56,493 & & 6,940 & & & & 53,671 & 6,593 \\
\hline 23 & 56,097 & & 6,265 & & & & 55,281 & 6,174 \\
\hline 24 & 55,704 & & 5,655 & & & & 56,940 & 5,781 \\
\hline 25 & 55,315 & 163,500 & 20,196 & & & & 58,648 & 5,413 \\
\hline TOPLAM & 2,910 & 676 & $1,346,146$ & & 623,054 & & 1,051,886 & 955,563 \\
\hline
\end{tabular}


Tablo 7. Yatırımın kredi ile yapılması durumunda nakit akış çizelgesi

\begin{tabular}{|c|c|c|c|c|c|c|c|c|c|}
\hline \multirow[t]{2}{*}{ Yillar } & \multicolumn{2}{|c|}{ Faydalar } & \multirow{2}{*}{$\begin{array}{c}\text { Faydaların } \\
\text { Bugünkü } \\
\text { Değeri }\end{array}$} & \multicolumn{5}{|c|}{ Masraflar } & \multirow{2}{*}{\begin{tabular}{|c} 
Masrafların \\
Bugünkü \\
Değeri
\end{tabular}} \\
\hline & $\begin{array}{c}\text { Yıllık } \\
\text { kazanç }\end{array}$ & $\begin{array}{l}\text { Hurda } \\
\text { Değeri }\end{array}$ & & $\begin{array}{l}\text { Arazi } \\
\text { Bedeli }\end{array}$ & $\begin{array}{c}\text { Ekipman } \\
\text { Maliyetleri }\end{array}$ & $\begin{array}{c}\text { Diğer İlk } \\
\text { Yatırım } \\
\text { Maliyetleri }\end{array}$ & $\begin{array}{c}\text { Kredi } \\
\text { Taksitleri }\end{array}$ & \begin{tabular}{|c} 
İşletme ve \\
Bakım \\
Maliyetleri
\end{tabular} & \\
\hline 0 & 0 & & & 54,054 & 545,000 & 24,000 & 0 & 0 & 623,054 \\
\hline 1 & 193,507 & & 175,915 & & & & 80,688 & 28,851 & 99,581 \\
\hline 2 & 192,152 & & 158,804 & & & & 80,688 & 29,717 & 91,244 \\
\hline 3 & 190,807 & & 143,356 & & & & 80,688 & 30,608 & 83,619 \\
\hline 4 & 189,472 & & 129,412 & & & & 80,688 & 31,526 & 76,644 \\
\hline 5 & 188,145 & & 116,823 & & & & 80,688 & 32,472 & 70,264 \\
\hline 6 & 186,828 & & 105,460 & & & & 80,688 & 33,446 & 64,426 \\
\hline 7 & 185,520 & & 95,201 & & & & 80,688 & 34,450 & 59,084 \\
\hline 8 & 184,222 & & 85,941 & & & & 80,688 & 35,483 & 54,195 \\
\hline 9 & 182,932 & & 77,581 & & & & 80,688 & 36,548 & 49,719 \\
\hline 10 & 181,652 & & 70,035 & & & & 80,688 & 37,644 & 45,622 \\
\hline 11 & 61,031 & & 21,391 & & & & & 38,773 & 13,590 \\
\hline 12 & 60,604 & & 19,310 & & & & & 39,937 & 12,725 \\
\hline 13 & 60,179 & & 17,432 & & & & & 41,135 & 11,915 \\
\hline 14 & 59,758 & & 15,736 & & & & & 42,369 & 11,157 \\
\hline 15 & 59,340 & & 14,205 & & & & & 43,640 & 10,447 \\
\hline 16 & 58,924 & & 12,824 & & & & & 44,949 & 9,782 \\
\hline 17 & 58,512 & & 11,576 & & & & & 46,297 & 9,160 \\
\hline 18 & 58,102 & & 10,450 & & & & & 47,686 & 8,577 \\
\hline 19 & 57,696 & & 9,434 & & & & & 49,117 & 8,031 \\
\hline 20 & 57,292 & & 8,516 & & & & & 50,590 & 7,520 \\
\hline 21 & 56,891 & & 7,688 & & & & & 52,108 & 7,041 \\
\hline 22 & 56,493 & & 6,940 & & & & & 53,671 & 6,593 \\
\hline 23 & 56,097 & & 6,265 & & & & & 55,281 & 6,174 \\
\hline 24 & 55,704 & & 5,655 & & & & & 56,940 & 5,781 \\
\hline 25 & 55,315 & 163,500 & 20,196 & & & & & 58,648 & 5,413 \\
\hline TOPLAM & 2,91 & 676 & $1,346,146$ & & & & 806,883 & $\mathbf{1 , 0 5 1 , 8 8 6}$ & $1,451,358$ \\
\hline
\end{tabular}

Her iki senaryoda, yatırımın net bugünkü değeri faydaların bugünkü değerinden masrafların bugünkü değerleri çıkartılarak hesaplanmıştır. Benzer şekilde, fayda/masraf oranları faydaların bugünkü değerlerinin masrafların bugünkü değerlerine bölünmesi suretiyle bulunmuştur. Faydaların bugünkü değerini masrafların bugünkü değerine eşitleyen iç kârlılık oranları ise NBD'si pozitif olan öz sermaye senaryosu için Excel programında iskonto oranının artırılması, NBD'si negatif olan kredi senaryosu içinse azaltılması suretiyle hesaplanmıştır.

Yatırımın öz sermaye veya kredi ile yapılması durumları için projenin geri ödeme süreleri hesaplanmış olup Tablo 8'de gösterilmiştir. Bu yöntem paranın zaman değerini dikkate almayan bir yaklaşımla basit şekilde yıllık getiri miktarının yatırım maliyetlerini karşıladığı yılı ifade etmektedir. Yatırımın öz sermaye ile yapılması durumunda yatırımın 4. senede sermaye maliyetlerini geri ödediği ve pozitif net kâr sağladığı görülmüştür. Yatırımın kredi ile yapılması halinde ise geri ödeme süresi 9 yıla çıkmaktadır.

Tablo 6 ve Tablo 7'de gösterilen nakit akış çizelgelerinden faydalanılarak yatırımın öz sermaye veya kredi ile yapılması durumları için net bugünkü değer, iç kârlılık oranı ve fayda/masraf oranları hesaplanmış olup elde edilen sonuçlara Tablo 9'da yer verilmiştir. 
Tablo 8. Yatırımın öz sermaye veya kredi ile yapılması durumunda geri ödeme süreleri

\begin{tabular}{|c|c|c|c|}
\hline \multicolumn{4}{|c|}{ Öz Sermaye ile Yatırımın Geri Ödeme Süresi } \\
\hline Yıllar & Fayda & Masraf & Net Kâr \\
\hline 0 & & 623.054 & -623.054 \\
\hline 1 & 193.507 & 28.851 & -458.398 \\
\hline 2 & 192.152 & 29.717 & -295.962 \\
\hline 3 & 190.807 & 30.608 & -135.763 \\
\hline $\mathbf{4}$ & $\mathbf{1 8 9 . 4 7 2}$ & $\mathbf{3 1 . 5 2 6}$ & $\mathbf{2 2 . 1 8 2}$ \\
\hline 5 & 188.145 & 32.472 & 177.855 \\
\hline 6 & 186.828 & 33.446 & 331.237 \\
\hline 7 & 185.520 & 34.450 & 482.308 \\
\hline 8 & 184.222 & 35.483 & 631.047 \\
\hline 9 & 182.932 & 36.548 & 777.431 \\
\hline 10 & 181.652 & 37.644 & 921.439 \\
\hline
\end{tabular}

\begin{tabular}{|c|c|c|c|}
\hline \multicolumn{5}{|c|}{ Kredi ile Yatırımın Geri Ödeme Süresi } \\
\hline Yıllar & Fayda & Masraf & Net Kâr \\
\hline 0 & & 623.054 & -623.054 \\
\hline 1 & 193.507 & 109.539 & -539.087 \\
\hline 2 & 192.152 & 110.405 & -457.339 \\
\hline 3 & 190.807 & 111.296 & -377.828 \\
\hline 4 & 189.472 & 112.215 & -300.571 \\
\hline 5 & 188.145 & 113.160 & -225.586 \\
\hline 6 & 186.828 & 114.135 & -152.893 \\
\hline 7 & 185.520 & 115.138 & -82.510 \\
\hline 8 & 184.222 & 116.171 & -14.460 \\
\hline $\mathbf{9}$ & $\mathbf{1 8 2 . 9 3 2}$ & $\mathbf{1 1 7 . 2 3 6}$ & $\mathbf{5 1 . 2 3 6}$ \\
\hline 10 & 181.652 & 118.332 & 114.556 \\
\hline
\end{tabular}

Tablo 9. Finansal analiz sonuçları

\begin{tabular}{|l|c|c|}
\hline & Yatırımın Öz Sermaye ile Yapılması & Yatırımın Kredi ile Yapılması \\
\hline Net Bugünkü Değer & 390,583 ABD Doları & $-105,212$ ABD Doları \\
\hline İç Kârlılık Oranı & $\% 22.35$ & $\% 6.76$ \\
\hline Fayda/Masraf Oranı & 1.409 & 0.928 \\
\hline Geri Ödeme Süresi & 4 Yıl & 9 Yı1 \\
\hline
\end{tabular}

Tablo 9'da yer verilen finansal analiz sonuçları incelendiğinde, Van ili Edremit ilçesinde yapılması planlanan $1 \mathrm{MW}$ lisanslı GES yatırımın maliyetlerinin tamamen öz sermaye ile karşılanması durumunda, yatırımın net bugünkü değerinin pozitif bir değer olduğu, iç kârlılık oranının seçilen \%10 iskonto (verim) oranının 2 katından daha fazla olarak hesaplandığı, bu durumda yatırımdan \%22.35 orana kadar kâr sağlama beklentisi altında yatırımın kârlı olarak değerlendirilebileceği, fayda/masraf oranının da 1'den büyük bir değer olduğu ve geri ödeme süresinin 4 yıl olarak hesaplandığ1 görülmektedir. Bu kapsamda, mevcut ilk yatırım maliyetleri, elektrik satış fiyatları, ekonomik koşullar ile getiri oranları göz önünde bulundurulduğunda söz konusu GES yatırımının öz sermaye ile yapılmasının oldukça kârlı bir yatırım olduğu sonucuna varılmaktadır.

Aynı yatırımın 10 yıl geri ödemeli TurSEFF yenilenebilir enerji kredisi ile yapılması halinde ise yatırımın net bugünkü değeri negatif olarak bulunmuş, aynı zamanda kazanç ve maliyetlerin bugünkü değerlerini eşitleyen iç kârlılık oranı ise kabul edilen \%10 iskonto oranından daha düşük olacak şekilde \%6.76 olarak hesaplanmıştır. Ayrıca yatırımın fayda/masraf oranı 1'den küçük ve yatırımın geri ödeme süresi de 9 yıl olarak GES yatırımları için günümüz koşullarında yatırım yapılabilir kabul edilen geri ödeme sürelerinden daha uzun hesaplanmıştır. Bu bağlamda, söz konusu yatırımın beklenen kâr payına göre tamamen kredi ile yapılması kârlı bir yatırım olarak değerlendirilmemektedir. Diğer taraftan, 1 MW GES yatırımı için gerekli sermaye maliyetinin bir kısmının öz sermaye ile kalan kısmının ise kredi ile karşılanması da sıklıkla karşılaşılan bir uygulamadır. Yatırımın bu şekilde yapılması halinde belirli bir iskonto oranına kadar yatırım kârlı şekilde gerçekleştirilebilmektedir.

Yatırım kararının verilmesinde, yatırımcının kâr oranı beklentisi ve ekonomik durumu, yatırım yapılacak bölge ve arazinin yatırıma uygunluğu, ekipman maliyetleri gibi birçok etken bulunmakla beraber bu çalışmada kullanılan finansal analiz yöntemlerinin benzer sonuçlar verdiği görülmüştür. Dolayısıyla özellikle yenilenebilir enerjiye dayalı yatırım kararı verilmesinde, net bugünkü değer, iç kârlılık oranı, fayda/masraf oranı gibi paranın zaman değerini dikkate alan finansal analiz yöntemlerinden etkin bir şekilde faydalanılabileceği ve yatırım kararının verilebilmesine esas doğru sonuçlar elde edilebileceği söylenebilir. 


\section{Sonuç ve Öneriler}

Güneş enerji santrali yatırımları, kaynak potansiyelinin yüksekliği, görece olarak kurulum kolaylığı ve işletme-bakım maliyetlerinin diğer yenilenebilir enerji kaynaklarına kıyasla daha düşük seviyelerde olması dolayısıyla ülkemizde özellikle son beş yıl içerisinde büyük ivme kazanmış ve ülkemizin yenilenebilir enerjiye dayalı kurulu gücünün artışına büyük katkı sağlamıştır. Bu artışta, lisanssız üretim kapsamında kurulan küçük ölçekli GES yatırımları en büyük paya sahiptir. Ayrıca 600 MW bağlantı kapasitesi için yapılan GES önlisans yarışmaları kapsamındaki projeler ile önümüzdeki süreçte daha da yaygınlaşacağı öngörülen YEKA modeli kapsamındaki projelerin de önemli bir yere sahip olduğu vurgulanmalıdır. GES kurulumu için ülkemizde yatırımcılar tarafından oldukça yüksek bir talep bulunmakta, dolayısıyla yeterli kâr getirisi sağlayan yatırım açısından verimli projelerin hayata geçirilmesi büyük önem taşımaktadır.

$\mathrm{Bu}$ çalışmada, yıllık güneşlenme süresi bakımından GES kurulumu için uygun olduğu değerlendirilen Van ili Edremit ilçesinde 1 MW kurulu gücünde lisanslı GES yatırımının PVGIS çevrim içi veri tabanı kullanılarak enerji hesaplamaları yapılmış, akabinde farklı yöntemlere dayalı finansal analizi gerçekleştirilerek projenin ekonomik açıdan yatırım yapılabilir olup olmadığı incelenmiştir.

İlk olarak bölgenin güneş enerjisi potansiyeli değerlendirilerek yatırım için uygun arazi seçimi yapılmış, sonrasında PVGIS çevrim içi veri tabanından faydalanılarak seçilen arazinin koordinat bilgilerine göre yıllık elektrik üretim miktarları hesaplanmıştır. Ayrıca piyasa araştırmaları sonucunda içinde bulunduğumuz yıla ilişkin ekipman ve diğer maliyet unsurları belirlenmiştir.

Sonraki bölümde yatırımın finansal analizinin yapılmasında kullanılan geri ödeme süresi, net bugünkü değer, iç kârlılık oranı ve fayda/masraf oranı yöntemlerinin esasları açıklanmış ve yatırımın finansal analiz çalışması, ilk yatırım maliyetlerinin öz sermaye veya TurSEFF yenilenebilir enerji kredisi ile karşılanmasına ilişkin iki farklı senaryo altında gerçekleştirilmiştir.

Yapılan finansal değerlendirme neticesinde, yatırımın tamamının öz sermaye ile yapılması durumunda; yatırımın net bugünkü değerinin pozitif olduğu, iç kârlılık oranının \%22.35 olduğu, fayda/masraf oranının ise 1.409 olduğu görülmüş ve yatırımın kârlı olacağı tespit edilmiştir. İlk yatırım maliyetlerinin kredi ile karşılanması durumunda ise \%10 kâr getirisi beklentisi altında yatırımın kabul edilebilir olmadığı, santralin ekonomik ömrü boyunca kazançların maliyetleri karşılamayacağı sonucuna varılmıştır. Bu durumda yatırımın, ancak kâr beklentisinin \%6.76'dan daha düşük olduğu koşullarda kârlı hale geleceği görülmüştür.

GES yatırımının geri ödeme süresi ise ilk yatırım maliyetlerinin öz sermaye ile karşılanması durumunda 4 yıl olurken kredi ile karşılanması durumunda 9 yıl olarak hesaplanmıştır. GES yatırımın saha, çatı gibi uygulama farklılıklarına, lisanslı veya lisanssız üretim kapsamında yapılıp yapılmamasına, tesisin kurulu gücüne veya kurulduğu yere göre geri ödeme süresi farkl1lık göstermekle birlikte GES yatırımı için 4 ila 7 yıl arasındaki geri ödeme süreleri günümüz koşullarında yatırım yapılabilir olarak nitelendirilmektedir. Bu çerçevede, ilk yatırım maliyetlerinin öz sermaye ile karşılanması halinde geri ödeme süresinin 4 yıl olduğu görüldüğünden yatırım yapılabilir sayılmakta, yatırım maliyetlerinin kredi ile karşılanması halinde ise 9 yıllık geri ödeme süresi yatırımın kârlı olmayacağını göstermektedir.

Bu çalışmada elde edilen finansal analiz sonuçları, genel anlamda santralde kullanılan güneş panellerinin teknoloji türüne, birim yüzeye düşen radyasyon (1şınım) miktarına ve panel verimine bağlı yıllık elektrik üretim miktarına, ilk yatırım maliyet tutarlarına ve elektrik satış fiyatına göre büyük oranda değişmektedir. Güneş enerjisine dayalı lisanslı üretim kapsamındaki santraller için mevcut alım garantisi fiyatı olan 13.3 ABD Doları cent/kWh, 30/06/2021 tarihine kadar işletmeye girecek üretim tesisleri için işletmeye giriş tarihinden itibaren 10 yıl süreyle geçerlidir. Diğer taraftan, 29/01/2021 tarihli ve 3453 sayılı Cumhurbaşkanı Kararı ile 01/07/2021 tarihinden 31/12/2025 tarihine kadar işletmeye girecek güneş enerjisine dayalı lisanslı faaliyette bulunan santraller için yeni alım garantisi fiyatının 32 kuruş/kWh (4.32 ABD Doları cent/kWh, 26 Şubat 2021 tarihli satış bazlı dolar kuru USD/TRY 7.4 [27]' e göre) ile başlayarak üçer aylık dönemler halinde güncellenmesine karar verilmiştir. Buna göre, piyasada artan rekabet koşulları ile kurulum maliyetlerindeki düşüşe bağlı olarak elektrik alım garantisi fiyatının da düşmesi, yatırımın kazanç oranlarını ve analiz sonuçlarını değiştirebilecek, dolayısıyla yatırım kararlarını büyük oranda etkileyebilecektir. Buradan hareketle, yaşanan teknolojik gelişmelerin, piyasa koşullarının ve arz-talep dengesinin yatırım kararı alınmasında büyük önemi olduğunu vurgulamakta fayda vardır. 
Yapılan bu çalışmanın, güneş enerji potansiyelinin yüksek olduğu Van ilinde gerçekleştirilmesi planlanan 1 MW lisanslı GES yatırımının ekonomik açıdan kârlı olup olmadığının günümüz ekonomik koşulları altında incelenmesiyle, farklı illerde ve farklı uygulamalar kapsamında yapılacak GES yatırım analizi çalışmalarıyla karşılaştırma imkânı sunacağı ve çeşitli simülasyon programları ile yapılabilecek GES yatırım değerlendirmelerine katkı sağlayacağı düşünülmektedir.

\section{Yazarların Katkısı}

Çalışmada tüm katkı sorumlu yazara aittir.

\section{Çıkar Çatışması Beyanı}

Çalışmaya dair herhangi bir çıkar çatışması bulunmamaktadır.

\section{Araştırma ve Yayın Etiği Beyanı}

Yapılan çalışmada araştırma ve yayın etiğine uyulmuştur.

\section{Kaynaklar}

[1] Enerji ve Tabii Kaynaklar Bakanlığı Bilgi Merkezi, 2021. Güneş. https://enerji.gov.tr/bilgimerkezi-enerji-gunes (Erişim tarihi: 27.02.2021).

[2] Meteoroloji Genel Müdürlüğü, 2021. Türkiye Ortalama Güneşlenme Süresi (1988-2017). https://mgm.gov.tr/kurumici/turkiye-guneslenme-suresi.aspx (Erişim tarihi: 27.02.2021).

[3] Enerji İş̧leri Genel Müdürlüğü, 2018. Türkiye Güneş Enerjisi Potansiyel Atlası (GEPA). https://gepa.enerji.gov.tr/MyCalculator/ (Erişim tarihi: 27.02.2021).

[4] Türkiye Elektrik İletim Anonim Şirketi, Santral Kurulu Güç Raporları, 2021. Ocak 2021 Kurulu Güç Raporu. https://www.teias.gov.tr/tr-TR/kurulu-guc-raporlari (Erişim tarihi: 27.02.2021).

[5] E-mevzuat, 2021. 6446 sayılı Elektrik Piyasas1 Kanunu. https://www.mevzuat.gov.tr/mevzuat?MevzuatNo=6446\&MevzuatTur=1\&MevzuatTertip=5 (Erişim tarihi: 27.02.2021).

[6] Enerji Piyasası Düzenleme Kurumu, 2021. Elektrik Piyasası Üretim Lisansları. http://lisans.epdk.gov.tr/epvys-web/faces/pages/lisans/elektrikUretim/elektrikUretimOzetSorgu la.xhtml (Erişim tarihi: 27.02.2021).

[7] Sarı V., Özyiğit F.Y. 2020. Sivas Cumhuriyet Üniversitesi Yerleşkesinde Güneş Enerjisi Santralinin Ekonomik Analizi. Dokuz Eylül Üniversitesi Mühendislik Fakültesi Fen ve Mühendislik Dergisi, 22 (65), 517-526.

[8] Rüstemli S., Dinçer F. 2011. Van İli Elektrik Enerjisi Üretiminde Güneş Enerjisinin Mevcut Durumu ve Geleceği. Yüzüncüyıl Üniversitesi Fen Bilimleri Enstitüsü Dergisi, 16 (1): 22-33.

[9] Sarı V., Özyiğit F.Y. 2020. Sivas İlinin Farklı İlçelerinde Şebeke Bağlantılı Güneş Enerji Santrallerinin Tasarımı ve Analizi. Avrupa Bilim ve Teknoloji Dergisi, 20: 425-437.

[10] Bayrakçı H.C., Gezer T. 2019. Bir Güneş Enerjisi Santralinin Maliyet Analizi: Aydın İli Örneği. Teknik Bilimler Dergisi, 9 (2): 46-54.

[11] Kurbaş İ., Çifci A. 2019. Feasibility Study of a Solar Power Plant Installation: A Case Study of Lake Burdur, Turkey. El-Cezerî Fen ve Mühendislik Dergisi, 6 (3): 830-835.

[12] Demiryürek H.K., Arifoğlu U., Bolat M. 2020. Lebit Enerji Güneş Santralinin Pvsyst Programı İle Analizi. BEÜ Fen Bilimleri Dergisi, 9 (3): 1351-1363.

[13] Oral M. 2020. Solar energy potential of Turkey and evaluation of PV applications in local scale: Case of Karabük province. International Journal of Geography and Geography Education (IGGE), 42: 482-503.

[14] Arıkan Y., Çam E. 2017. Rüzgar ve Güneş Enerjisi Sistemlerinin Fizibilite Analizlerinin Web Tabanında Gerçekleştirilmesi. Uluslararası Mühendislik Araştırma ve Geliştirme Dergisi, 9 (1).

[15] Alcan Y., Demir M., Duman S. 2018. Sinop İlinin Güneş Enerjisinden Elektrik Üretim Potansiyelinin Ülkemiz Ve Almanya İle Karşılaştırarak İncelenmesi. El-Cezerî Fen ve Mühendislik Dergisi, 5 (1): 35-44. 
[16] Üçgül İ., Tüysüzoğlu E., Yakut M.Z. 2014. PV Çatı Uygulaması İçin Enerji Hesaplamas1 ve Ekonomik Analizi. Süleyman Demirel Üniversitesi Fen Bilimleri Enstitüsü Dergisi, 18 (2): 1-6.

[17] Taktak F., Ilı M. 2018. Güneş Enerji Santrali (GES) Geliştirme: Uşak Örneği. Geomatik Dergisi, 3 (1): $1-21$.

[18] Anonim, 2021. Van ili. https://tr.wikipedia.org/wiki/Van (Erişim tarihi: 28.02.2021).

[19] European Commission Joint Research Center Institute for Energy, 2010. Guidelines for PV Power Measurement in Industry. https://publications.jrc.ec.europa.eu/repository/bitstream/JRC57794 /eur-24359-en.pdf (Erişim tarihi: 28.02.2021).

[20] Güneş Enerjisi Potansiyel Atlası (GEPA), 2021. Van ili Global Radyasyon Değerleri. https://gepa.enerji.gov.tr/MyCalculator/pages/65.aspx (Erișim tarihi: 28.02.2021).

[21] Meteoroloji Genel Müdürlüğü, 2021. Van ili Ölçüm İstatistikleri. https://www.mgm.gov.tr/veridegerlendirme/il-ve-ilceler-istatistik.aspx?k=undefined\&m=VAN (Erișim tarihi: 28.02.2021).

[22] Ceylan E. 2021. Güneş Enerji Santrali Fizibilite Raporu-Kayseri örneği. http://makale.eceylan.com/wp-content/uploads/2015/03/G\%C3\%BCne\%C5\%9F-Enerji-Santrali -Fizibilite-Raporu.pdf (Erişim tarihi: 28.02.2021).

[23] Ceylan O., Taşdelen K. 2018. Isparta İli için Fotovoltaik Programlarının Simülasyon Sonuçlarının Doğruluğunun İncelenmesi. Afyon Kocatepe Üniversitesi Fen ve Mühendislik Bilimleri Dergisi, 18: 895-903.

[24] E-mevzuat, 2021. 5346 sayılı Yenilenebilir Enerji Kaynaklarının Elektrik Enerjisi Üretimi Amaçlı Kullanımına İlişkin Kanun. https://www.mevzuat.gov.tr/mevzuat?MevzuatNo=5346 \&MevzuatTur=1\&MevzuatTertip=5 (Erişim tarihi: 28.02.2021).

[25] EPİAŞ, 2021. Şeffaflık Platformu, Piyasa Takas Fiyatı. https://seffaflik.epias.com.tr/transparency/piyasalar/gop/ptf.xhtml (Erişim tarihi: 28.02.2021).

[26] Kahraman M.Ü. 2018. Kütahya Bölgesi Güneş ve Rüzgâr Enerji Potansiyellerinin TeknoEkonomik Analizi. Yüksek Lisans Tezi, Dumlupınar Üniversitesi, Fen Bilimleri Enstitüsü, Kütahya, 1-135.

[27] Türkiye Cumhuriyeti Merkez Bankas1, 2021. 26.02.2021 Günü Saat 15:30'da Belirlenen Gösterge $\begin{array}{lllll}\text { Niteliğindeki } & \text { Türkiye } & \text { Cumhuriyet } & \text { Merkez } & \text { Bankası }\end{array}$ https://www.tcmb.gov.tr/kurlar/kurlar_tr.html (Erişim tarihi: 28.02.2021).

[28] Solar Enerji, 2021. 1 MW GES Santrali Kurulum Maliyeti. https://www.powerenerji.com/1-mwgunes-enerji-santrali-ges-kurulu-maliyeti-aylik-yillik-geliri.html\#1_Mw_Guumlne351_Enerji_ Santrali_Kurulucak_304lin_Guumlne351lenme_De287erleri (Erişim tarihi: 28.02.2021).

[29] SMA Solar Technology, 2021. https://www.sma.com.tr/ (Erişim tarihi: 28.02.2021).

[30] Enerji Piyasası Düzenleme Kurumu, 2021. Elektrik Faturalarına Esas Tarife Tabloları. https://www.epdk.gov.tr/Detay/Icerik/3-1327/elektrik-faturalarina-esas-tarife-tablolari (Erișim tarihi: 06.03.2021).

[31] Gedik T., Akyüz K.C., Akyüz İ. 2005. Yatırım Projelerinin Hazırlanması ve Değerlendirilmesi (İç Karlılık Oranı ve Net Bugünkü Değer Yöntemlerinin İncelenmesi. ZKÜ Bartın Orman Fakültesi Dergisi, 7 (7): 51-61.

[32] Şenoğlu G. (2020). GES yatırımlarında geri dönüş süresi 4 yıla indi. Solar Energy Systems Magazine. https://www.gesdergisi.com/ges-yatirimlarinda-geri-donus-suresi-4-yila-indi/ (Erişim tarihi: 21.03.2021).

[33] TurSEFF Yenilenebilir Enerji Finansman1, (2021). https://www.turseff.org/solution/yenilenebilir-enerji-finansmani?ref=yenilenebilir-enerjifinansmani (Erişim tarihi: 21.03.2021).

[34] Başay V., Eken R., Yılmaz G. 2019. Orta Yükseklikte Dağlık Bölgelerde Kurulan Güneş Enerjisi Santralinde Fotovoltaik Modüllerin Yaşlanmasının Araştırılması. Uludağ Üniversitesi Mühendislik Fakültesi Dergisi, 24 (2): 325-336.

[35] Adak S., Cangi H., Yılmaz A.S. 2019. Fotovoltaik Sistemin Çıkış Gücünün Sıcaklık ve Işımaya Bağlı Matematiksel Modellemesi ve Simülasyonu. Uluslararası Mühendislik Araştırma ve Geliştirme Dergisi, 11 (1): 316-327. 